\title{
Genome-wide identification and evolutionary analysis of RLKs involved in the response to aluminium stress in peanut
}

\author{
Xin Wang ${ }^{1}$, Ming-Hua Wu' ${ }^{1}$, Dong Xiao ${ }^{1,2,3^{*}}$ (D), Ruo-Lan Huang ${ }^{1}$, Jie Zhan ${ }^{1,2,3}$, Ai-Qin Wang ${ }^{1,2,3}$ and \\ Long-Fei $\mathrm{He}^{1,2,3}$
}

\begin{abstract}
Background: As an important cash crop, the yield of peanut is influenced by soil acidification and pathogen infection. Receptor-like protein kinases play important roles in plant growth, development and stress responses. However, little is known about the number, location, structure, molecular phylogeny, and expression of RLKs in peanut, and no comprehensive analysis of RLKs in the Al stress response in peanuts have been reported.

Results: A total of 1311 AhRLKs were identified from the peanut genome. The AhLRR-RLKs and AhLecRLKs were further divided into 24 and 35 subfamilies, respectively. The AhRLKs were randomly distributed across all 20 chromosomes in the peanut. Among these AhRLKs, 9.53\% and 61.78\% originated from tandem duplications and segmental duplications, respectively. The ka/ks ratios of 96.97\% (96/99) of tandem duplication gene pairs and 98.78\% (646/654) of segmental duplication gene pairs were less than 1. Among the tested tandem duplication clusters, there were 28 gene conversion events. Moreover, all total of 90 Al-responsive AhRLKs were identified by mining transcriptome data, and they were divided into 7 groups. Most of the Al-responsive AhRLKs that clustered together had similar motifs and evolutionarily conserved structures. The gene expression patterns of these genes in different tissues were further analysed, and tissue-specifically expressed genes, including 14 root-specific Al-responsive AhRLKs were found. In addition, all $90 \mathrm{Al}$-responsive AhRLKs which were distributed unevenly in the subfamilies of AhRLKs, showed different expression patterns between the two peanut varieties (Al-sensitive and Al-tolerant) under Al stress.
\end{abstract}

Conclusions: In this study, we analysed the RLK gene family in the peanut genome. Segmental duplication events were the main driving force for $A h R L K$ evolution, and most $A h R L K s$ subject to purifying selection. A total of 90 genes were identified as Al-responsive AhRLKs, and the classification, conserved motifs, structures, tissue expression patterns and predicted functions of Al-responsive AhRLKs were further analysed and discussed, revealing their putative roles. This study provides a better understanding of the structures and functions of AhRLKs and Al-responsive AhRLKs.

Keywords: Peanut, RLK, Gene family, Genome-wide analysis, Al stress

*Correspondence: xiaodong@gxu.edu.cn

${ }^{1}$ National Demonstration Center for Experimental Plant Science

Education, College of Agriculture, Guangxi University, Nanning 530004,

China

Full list of author information is available at the end of the article

\section{Background}

Aluminium (Al) is one of the most harmful factors in plant growth in acidic soils, and $\mathrm{Al}$ can cause $25 \%$ to $80 \%$ yield losses depending on the crop $[1,2]$. Al signalling induces a series of physiological events in plant cells. The most obvious phenomena of $\mathrm{Al}$ toxicity are inhibition of cell elongation in the apical region and induction of programmed cell death (PCD) [3-5]. PCD is an active, 
orderly, and genetically controlled form of cell death and occurs in plants throughout development and in response to environmental stresses [6]. Early studies found that Altreatment can enhance $\mathrm{Fe}^{2+}$-induced lipid peroxidation and PCD in tobacco cells [7]. For decades, Al-induced PCD has been proven in many plant species including: soybean (Glycine max) [8], maize (Zea mays) [9], barley (Hordeum vulgare) [10], tomato (Lycopersicon esculentum) [11]and peanut (Arachis hypogaea) [12]. Al-induced PCD is mediated through two cell signal transduction pathways: a mitochondrial-dependent pathway and a nuclear-dominated mitochondrial-independent pathway [5]. However, Al signal information and its transmembrane transduction are unknown. Both pathways use plasma membrane and/or cell wall-localized receptors to sense environmental stimuli and efficiently transduce signals between cells, which perceive and transduce signals to modulate gene expression and/or enzyme activity as well as motility [13]. Receptor-like protein kinase (RLK) play important roles in the process of cell signal transduction, and are involved in a variety of plant physiological processes including: self-incompatibility [14], environmental signal processing [15], organ shape and meristem activity [16], hormone signal transduction [17], PCD [18], and tolerance to oxidative stress [19]. RLKs sense and transduce signals through protein interactions and phosphorylation [20]. Based on the structure of the extracellular domain, RLKs have been classified into several families such as S-RLKs, LRR-RLKs, EGF-RLKs, LecRLKs, TNFR-RLKs and PR5K-RLKs [21].While many RLKs involved in the environmental stress response have been found, few RLKs have been reported to be involved in $\mathrm{Al}$ stress response. WAK1, which mediates the interaction between the cell wall and cytoplasm and may participate in cell elongation and morphogenesis [22], was the first RLK that was found to be involved in the $\mathrm{Al}$ stress response. Theoverexpression of WAK1 was reported to enhance $\mathrm{Al}$ tolerance in Arabidopsis [23]. The results showed that $R L K$ s play an important role in $\mathrm{Al}$-induced $\mathrm{PCD}$, but the mechanism of $R L K \mathrm{~s}$ in the regulation of $\mathrm{Al}-$ induced PCD is unknown.

Peanuts are an important oil crop worldwide. Aldependent inhibition of growth causes a reduction in peanut yield in acidic soil. There is no comprehensive analysis of the RLK gene family in the peanut. In the present study, recently released peanut whole genome sequence data (http://peanutgr.fafu.edu.cn/index.php) were utilized to analyse the RLK gene family in peanut. A total of 1311 AhRLKs have been identified. The LRRRLKs and LecRLKs were further divided into 24 and 35 subfamilies, respectively based on a phylogenetic analysis. The evolution and collinearity of $A h R L K$ s were investigated. The evolutionary patterns of the RLK gene family were tested by investigating gene duplication events in the peanut. In addition, $90 A h R L K \mathrm{~s}$ in response to $\mathrm{Al}$ stress were identified by transcriptomic analysis, and the expression profiles of $A h R L K \mathrm{~s}$ at different $\mathrm{Al}$ treatment time-points were comprehensively determined. These results will provide a basis for further research on the evolution and physiological functions of $A h R L K \mathrm{~s}$ in response to $\mathrm{Al}$ stress in the peanut.

\section{Results \\ Identification of AhRLKs in the peanut}

To identify the members of AhRLKs in the peanut, we downloaded publicly available peanut genome sequence data and used the Arabidopsis RLK sequence as a query to perform a genome-wide similarity search. After filtration of the sequence, a total of 1311 AhRLKs that contained at least one kinase domain were initially identified, including 548 LRR-RLKs, 274 LecRLKs, 83 cysteine-rich RLKs, 76 EGF RLKs, 49 proline-rich RLKs, 46 s-domain RLKs, 22 TMK-RLKs, 2 TNFR-RLKs, 1 RRO-RICH RLK, 28 RLCK-RLKs, 24 LysM-RLKs, and 158 no obvious domains (Additional files 1 and 2). LRR-RLKs and LecRLKs were considered for further analyses.

\section{Phylogenetic analysis of LRR-RLKs and LecRLKs in the peanut}

To explore the phylogenetic relationships within the AhRLK class, full-length amino acid sequences of LRRRLKs and LecRLKs were analysed separately. AhLRRRLKs and AhLecRLKs were clustered with AtLRR-RLKs (209) and AtLecRLKs (76) respectively. The RLK classification in Arabidopsis was followed to analyse the phylogenetic relationship of peanut RLKs. AhLRR-RLKs were divided into 24 subclades in the ML tree (Fig. 1). The largest subclade LRR-XI contains 74 members, while the smallest subclade LRR-V contains only 1 member. Following the classification standards of Marcella [24] and Klass [25], peanut LecRLKs were classified into 35 subfamilies and subdivided into 3 classes: C-type LecRLKs (C-LecRLKs), L-type LecRLKs (L-LecRLKs) and G-type LecRLKs (G-LecRLKs) (Fig. 2). The largest subclades G-LecRLKs-XI and L-LecRLKs-IX contains 37 and 28 members separately, while no members from G-LecRLKs-VIb, G-LecRLKs-VIII, G-LecRLKs-VII, G-LecRLKs-X, G-LecRLKs-III, L-LecRLKs-VI, L-LecRLKs-I, L-LecRLKs-II, L-LecRLKs-III, and L-LecRLKs-V were found in the peanut.

\section{Chromosomal location and gene duplication of $A h R L K s$}

Physical positions of AhRLKs obtained from the "Peanut Genome resource" (http://peanutgr.fafu.edu.cn/) [26] were used to map them onto peanut chromosomes. Chromosome location information demonstrated that 


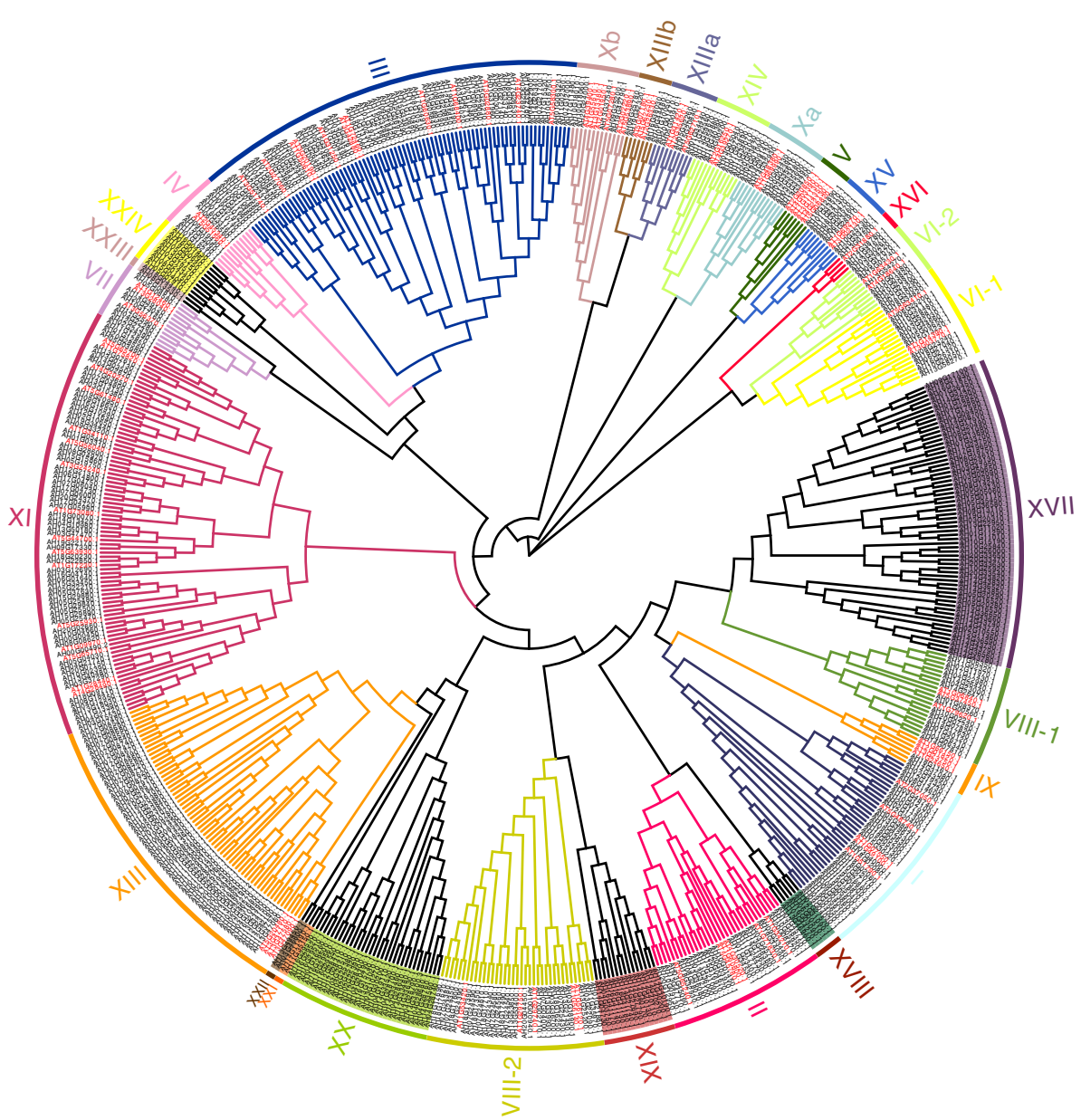

Fig. 1 Phylogenetic analysis and classification of peanut and A. thaliana LRR-RLK proteins. The phylogenetic tree was established with full sequences using the maximum-likelihood method with 1000 bootstrap replications and the evolutionary distances were computed using the p-distance method. Red sequences indicate the AtLRR-RLKs. Each RLK clade is depicted by a different colour, representing the 24 clades that were identified. Labelled lines on the outside of the tree represent clade names as defined in the text

all the AhRLKs were unevenly distributed among the 20 chromosomes of the peanut, and $1.14 \%(15 / 1311)$ did not show assembly information (Fig. 3). Many AhRLKs were located on chromosomes $14(111,8.47 \%)$ and 13 (106, 8.09\%), while only 31 (2.36\%) AhRLKs were located on chromosome 6. Regarding LRR-RLKs, subfamilies LRR-XI and LRR-III were present on all chromosomes, while others were found only on some chromosomes. The majority of the LRR-RLKs and LecRLKs were located on chr 3, 13, 8 and 18 (Additional file 3), in particular, all members of the G-LecRLKs-XVII and G-LecRLKs-VIa subfamilies were distributed on chr 8 and 18 (Additional file 4, Fig. 4).

Gene replication events play an important role in the evolution of new functions of proteins and the expansion of genomes. Segmental duplication and tandem duplication are the main causes of the expansion of gene families in plants [27]. The position of two or more $A h R L K \mathrm{~s}$ on the chromosome within $100 \mathrm{~kb}$ was considered a tandem duplication cluster. The results showed that approximately $9.53 \%(125 / 1311)$ of the genes were located in tandem duplication regions and constituted 52 clusters (Additional file 5). Among these genes, 5.66\% (31/548) of AhLRR-RLKs and 17.51\% (48/274) of AhLecRLKs were located in regions with tandem duplications. The largest tandem duplication cluster contained five genes, while the smallest cluster contained only two. Approximately $61.78 \%(810 / 1311)$ of the gene (810/1311) genes were located in segmental duplication regions. Up to $66.60 \%(365 / 548)$ of AhLRR-RLKs and 37.96\% (104/274) of AhLecRLKs were located in regions with segmental duplications. To investigate the selection forces acting upon individual $A h R L K \mathrm{~s}$, the ratio of the nonsynonymous 


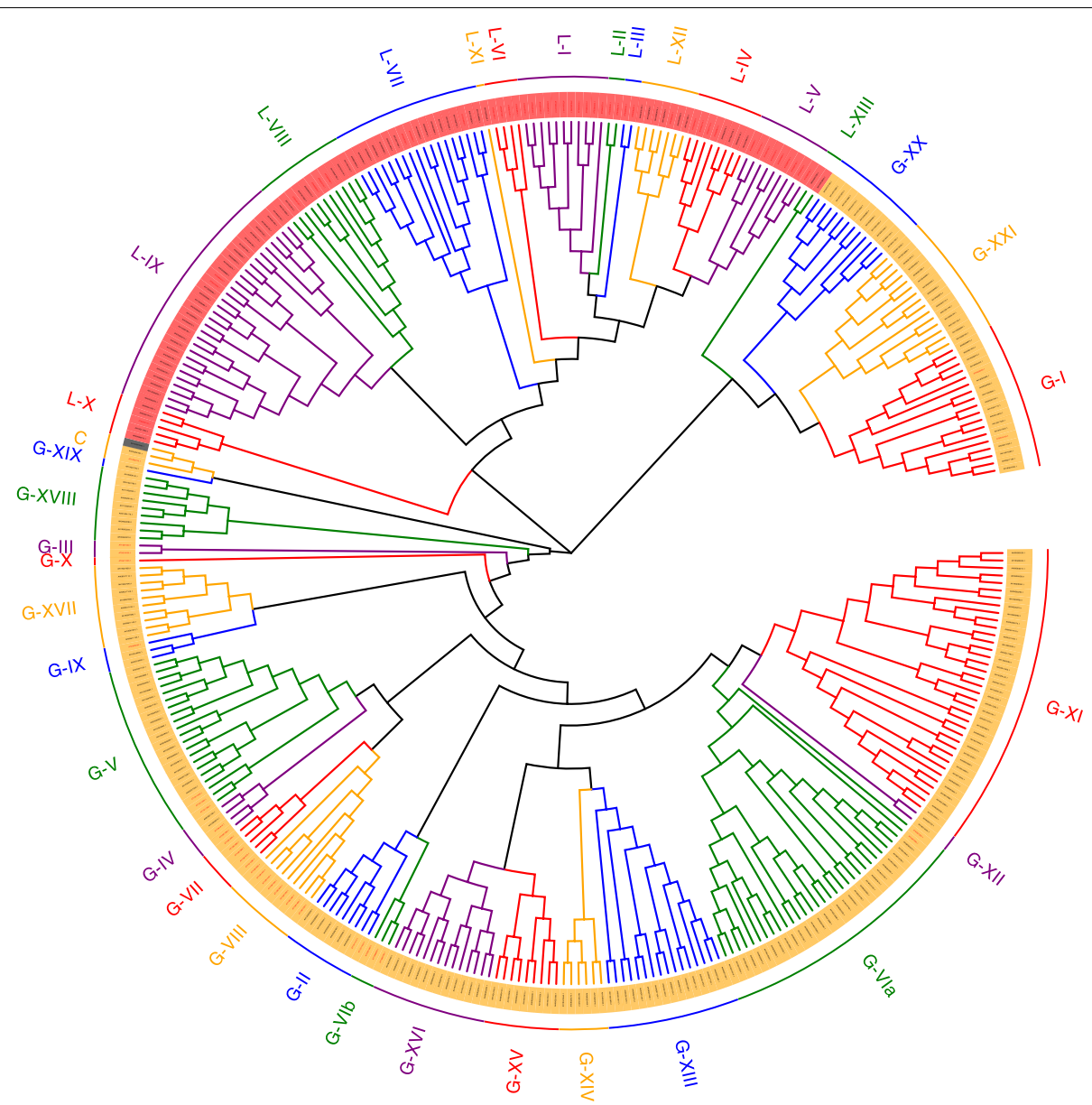

Fig. 2 Phylogenetic analysis and classification of peanut and A. thaliana LecRLK proteins. The phylogenetic tree was established with full sequences using the maximum-likelihood method with 1000 bootstrap replications and the evolutionary distances were computed using the $p$-distance method. Red sequences indicated the AtLecRLKs. Each RLK clade was depicted by a different colour, representing the 35 clades that were identified; labelled lines on the outside of the tree represent clade names as defined in the text

substitution rate to the synonymous substitution rate $(\mathrm{Ka} / \mathrm{Ks})$ was calculated. Among the 99 tandem duplicated gene pairs, the $\mathrm{Ka} / \mathrm{Ks}$ ratios of $96.97 \%(96 / 99)$ of the gene pairs were less than 1 and $2.02 \%(2 / 99)$ were more than 1 . One tandem duplication gene pair could not calculate the $\mathrm{Ka} / \mathrm{Ks}$ value. Among the 654 segmental duplication gene pairs, the $\mathrm{Ka} / \mathrm{Ks}$ ratios of 646 pairs $(98.78 \%)$ were less than 1 , and 4 pairs $(0.61 \%)$ were more than 1 . For four segmental duplication gene pairs $\mathrm{Ka} / \mathrm{Ks}$ values could not be calculated (Fig. 5). In addition, we calculated the divergence time with the formula $\mathrm{T}=\mathrm{Ks} / 2 \mathrm{r}$, in which $\mathrm{r}$ is the rate of divergence for nuclear genes from plants. The $r$ of dicotyledonous plants was taken to be $1.5^{*} 10^{\wedge}-8$ synonymous substitutions per site per year according to the methods of Koch [28]. The results showed that $82.82 \%(82 / 99)$ of tandem duplication events occurred 0-10 MYA, and $72.78 \%(476 / 654)$ of segmental duplication events occurred from 0-30 MYA (Additional file 6). Gene conversions play an important role in the coevolution of duplicated genes. Among the 52 tandem duplication clusters, 19 (36.54\%) clusters showed statistically significant gene conversion events $(\mathrm{P}<0.05)$. A total of 28 gene transformation events occurred in 52 tandem duplication clusters. The tract length of gene conversion ranged size from 16 to $1771 \mathrm{bp}$ (Additional file 7).

\section{Phylogenetic analysis of Al-responsive AhRLKs}

In a previous study, we performed a transcriptome analysis to identify differentially expressed genes (DEGs) and pathways between two peanut cultivars under Al Stress [29]. In this study, we scrutinized transcriptome data to detect the AhRLKs involved in the $\mathrm{Al}$ response. Genes with log2-transformed ratio FPKM values greater than 1 or less than -1 were defined as differentially expressed genes. A total of $90 \mathrm{Al}$-responsive 


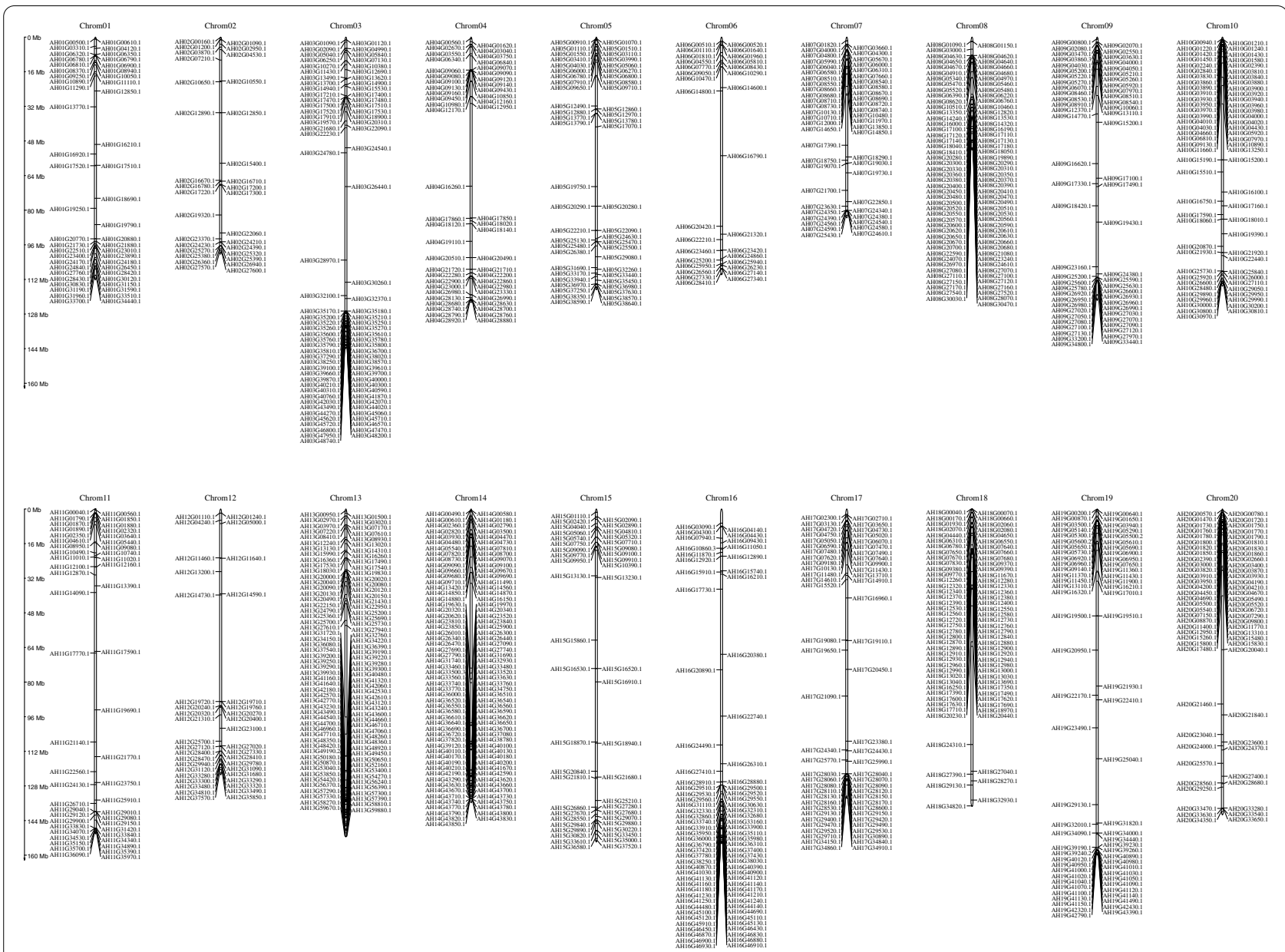

Fig. 3 Genomic distribution of AhRLKs across peanut chromosomes. Chromosomal locations of AhRLKs are indicated based on the physical position of each gene. The positions of genes on each chromosome were drawn with MG2C (Map Gene 2 Chromosome v2) software and the number of chromosomes was labelled on the top of each chromosome

AhRLKs, including 44 LRR-RLKs, 19 LecRLKs, 8 cysteine-rich RLKs, 1 EGF-RLKs, 2 proline-rich RLKs, 4 s-domain RLKs, 1 TMK RLK, 1 RLCK RLK, 1 LysM domain RLK, and 9 no obvious domains (Additional file 2). To reveal the evolutionary relationships of these proteins, a phylogenetic tree was constructed using the ML method (Fig. 6). Phylogenetic analysis of all 90 AhRLKs revealed that the Al-responsive AhRLKs were further classified into 7 groups, including $48.9 \%$ LRRRLKs, 21.1\% LecRLKs and 8.9\% CRKs. The phylogenetic tree showed that most of these genes belonged to LRR-RLKs and LecRLKs, covering the main subfamilies of LRR-RLKs and LecRLKs. Interestingly, these $\mathrm{Al}$ responsive AhRLKs were evenly distributed across the LecRLK family, but unevenly distributed across the LRR-RLK families, focusing on LRR-III, LRR-XI, LRRXII, LRR-VIII-1, and LRR-VIII-2.

\section{Characterization of the amino acid sequences and gene structure of Al stress-related AhRLKs}

As shown in Fig. 7, $90 \mathrm{Al}$ stress-related AhRLKs were divided into 7 groups. The diversification of exons/ introns has been reported to be an important reason for the evolution of certain gene families [30]. The distribution of exons/introns of $A h R L K$ s was further analysed. The results showed that $7.8 \%$ of $\mathrm{Al}$ stress-related $A h R L K \mathrm{~s}$ (7/90) had no introns. One, two and three introns were found in 30\% (27/90), 15.6\% (14/90) and 1.1\% (1/90) $\mathrm{Al}$ stress-related $A h R L K \mathrm{~s}$, respectively. Meanwhile, $45.6 \%$ (41/90) of the genes had more than three introns. All genes in subgroups I, II and VII contained more than three introns. Among these 30 genes, only one was LRRRLK gene in subgroup II while 15 were LecRLKs in subgroups I and II (Fig. 6, Additional file 2).The majority of genes in subgroups III, IV and VI contained one or two 


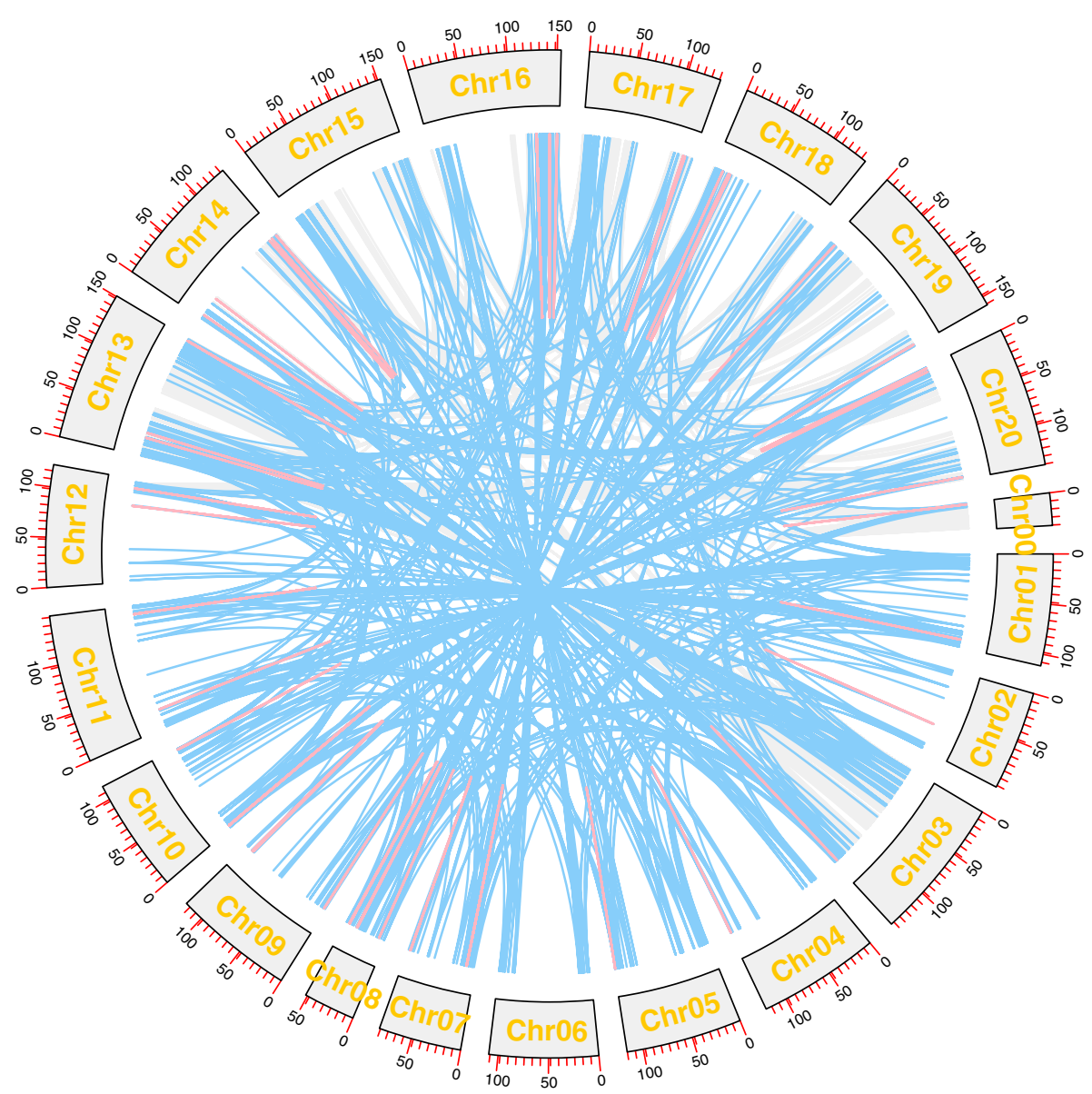

Fig. 4 Schematic representations of the interchromosomal relationships of the AhRLKs. The red lines indicate tandem duplicated gene pairs; the blue lines indicate segmented duplicated gene pairs

introns, of which $70.6 \%(36 / 51)$ were LRR-RLKs, and $7.8 \%(4 / 51)$ were LecRLKs. This result was similar to the study in which most LRR-RLKs in Arabidopsis had fewer than three introns [31]. Moreover, to analyse the diversity of the $\mathrm{Al}$ stress-related AhRLKs, the MEME tool was used to predict putative motifs of these proteins. A total of 5 different motifs were detected in $\mathrm{Al}$ stress-related AhRLKs and named motifs 1 to 5 (Additional file 8). Genes in subgroup I 82.4\% (14/17), 70\% (7/10) of genes in subgroup II, $50 \%$ of genes in subgroup III, $42.9 \%(6 / 14)$ of genes in subgroup IV, $88.9 \%$ (8/9) of genes in subgroup $\mathrm{V}, 75.8 \%(25 / 33)$ of genes in subgroups VI, and 33.3\% $(1 / 3)$ of genes in subgroup VII were shown to contain the same motif composition as motif 3-motif 4-motif 1-motif 2-motif 5.

\section{Expression profiles of Al-responsive AhRLKs in different tissues}

To further understand the role of Al-responsive $A h R L K \mathrm{~s}$ in peanut growth and development, the expression profiles of $\mathrm{Al}$-responsive $A h R L K \mathrm{~s}$ from different organs, including leaves, stems, florescence, roots and root tips, were tested in a cultivated variety (A. hypogaea L.) using transcriptomic data (Fig. 8). Among these Al-responsive AhRLKs, the majority (78/90, 86.7\%) were expressed in all organs examined. Six genes (6.7\% AH16G41130.1, AH07G04000.1, AH07G24540.1, AH07G24580.1, AH08G04680.1, and $A H 16$ G09430.1) were expressed at a high level (value $>5$ ) in leaves, 12 genes (13.3\% AH05G37250.1, AH04G28680.1, AH16G41130.1, AH01G21880.1, AH07G04000.1, AH07G24540.1, AH07G24580.1, AH03G13700.1, AH10G03910.1, AH08G04680.1, $A H 08 G 04640.1$, and $A H 16 G 09430.1)$ in stems, 6 genes (6.7\%, AH16G41130.1, AH01G21880.1, AH07G04000.1, AH07G24540.1, AH08G04640.1, and AH16G09430) in florescences, and 14 genes (15.6\%, AH07G04000.1, AH03G13700.1, AH10G03910.1, AH08G04680.1, AH08G04640.1, AH16G09430.1, AH14G07810.1, AH03G21680.1 AH19G41030.1, AH13G57290.1, 


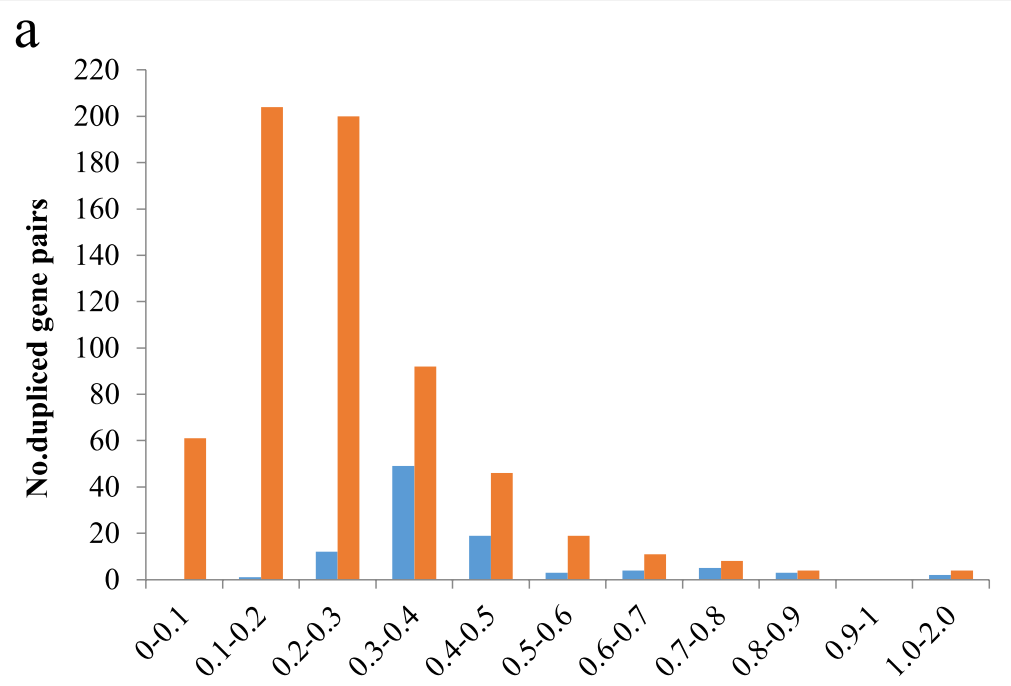

Tandem

- Segmental

$\mathrm{Ka} / \mathrm{Ks}$ value

$\mathrm{b}$

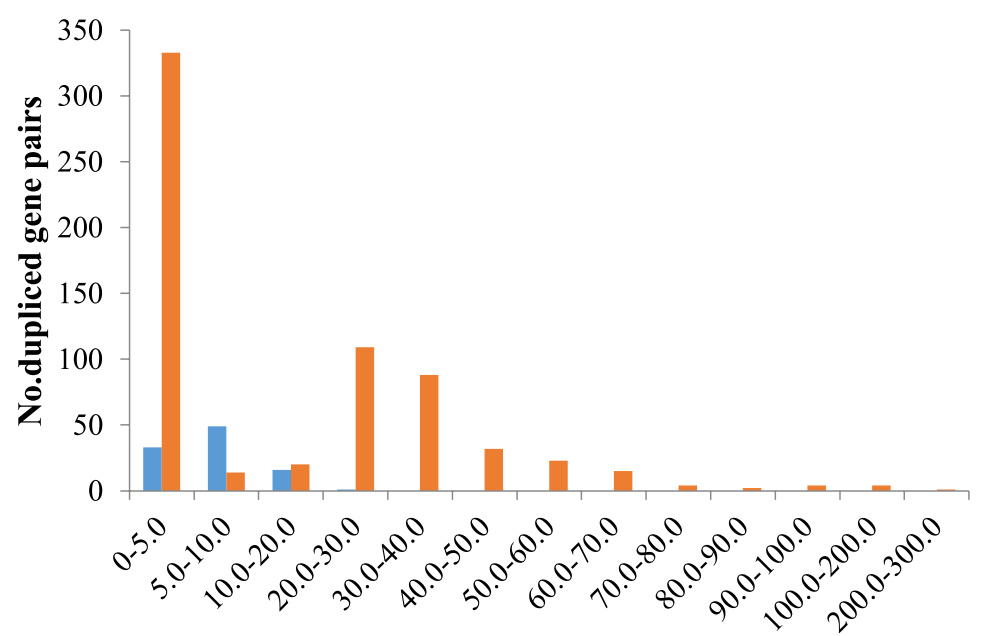

Divergence Time(MYA)

Fig. 5 The distribution of Ka/Ks values and divergence time (MYA) in all tandem and segmental duplicated AhRLKs. a The distribution of Ka/Ks values in all tandem and segmental duplicated AhRLKs. b The distribution of divergence time (MYA) in all tandem and segmental duplicated AhRLKS

AH10G29990.1, AH08G20520.1, AH08G06390.1, and AH01G04120.1) in roots or root tips.

\section{Expression patterns of Al-responsive AhRLKs under Al} stress

To further investigate the putative functions of Alresponsive $A h R L K \mathrm{~s}$, an $\mathrm{RNA}-\mathrm{Seq}$ dataset that was generated from different $\mathrm{Al}$ treatment time points were utilized to reveal the expression profiles of these genes under $\mathrm{Al}$ stress. The expression profiles of $\mathrm{Al}-$ responsive $A h R L K s$ are shown in histograms (Fig. 9).
As shown in Fig. 9, 41.1\% (37/90) of AhRLKs exhibited $>$ twofold upregulation under Al stress for $8 \mathrm{~h}$ in 99-1507. A total of $12.2 \%(11 / 90)$ and $8.9 \%(8 / 90)$ of $A h R L K$ s exhibited $>$ twofold down regulation under $\mathrm{Al}$ stress for $8 \mathrm{~h}$ in $\mathrm{ZH} 2$ and 99-1507, respectively. Among the AhRLKs, 3.3\% (3/90) and 12.2\% (11/90) exhibited $>$ twofold up regulation in the $24 \mathrm{~h}$ vs $0 \mathrm{~h}$ Al-treatment comparison, 6.7\% (6/90) and 1.1\% (1/90) $A h R L K$ s exhibited $>$ twofold down regulation in $24 \mathrm{~h}$ vs $0 \mathrm{~h} \mathrm{Al-treatment} \mathrm{comparison} \mathrm{in} \mathrm{the} \mathrm{ZH2} \mathrm{and} \mathrm{99-1507,}$ respectively (Additional file 9). 


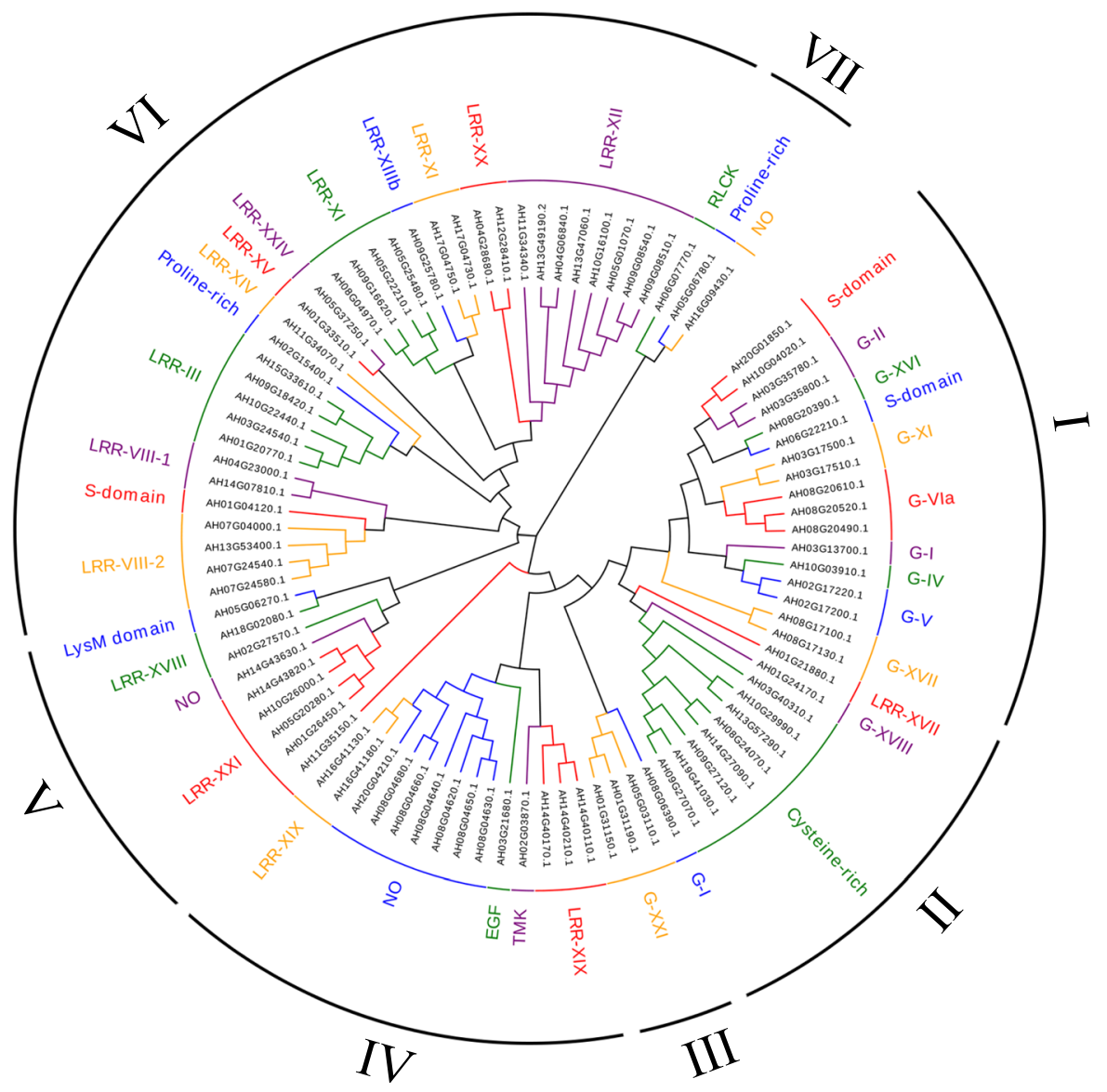

Fig. 6 Phylogenetic analysis of Al-responsive AhRLKs. The full-length amino acid sequences of 90 Al-responsive AhRLKs were aligned by Clustal $X$, and the phylogenetic tree was constructed using MEGA 7. All Al-responsive AhRLKs were classified into 7 distinct groups based on the nomenclature of Arabidopsis LRR-RLKs and LecRLKs

\section{Discussion}

\section{Segmental duplication events played an important role} in AhRLK family evolution

RLKs are involved in a variety of plant physiological processes and various abiotic and biotic stress responses [32, 33]. In this study, a total of 1311 AhRLKs, including 548 LRR-RLKs, 274 LecRLKs, 83 cysteine-rich RLKs, 76 EGF-RLKs, 49 proline-rich RLKs, 46 s-domain $R L K s, 22$ TMK-RLKs, 2 TNFR-RLKs, 1 RRO-RICH RLK, 28 RLCKRLKs, 24 LysM-RLKs, and 158 no obvious domain RLKs, were identified from whole peanut genome sequences (Additional file 1).

The 548 LRR-RLKs were classified into 24 subfamilies (I to XXIV) based on their phylogenetic relationship with Arabidopsis, which was 2 times the number of Arabidopsis LRR-RLKs (Fig. 1). In general, the number of LRR-RLKs for most of the subfamilies among the peanut was two times the number of LRR-RLKs of Arabidopsis, except LRR-XII, LRR-XIV, LRR-XV and LRR-XVI, which had more than three times the number of members of Arabidopsis. Only one subfamily, LRR-V, had fewer members than Arabidopsis. The number of LecRLKs was over 3 times the number of AtLecRLKs (Fig. 2). The subfamilies in the peanut such as L-LecRLK-VII, L-LecRLKs-IX and G-LecRLKs-VIa were much larger than the subfamilies in Arabidopsis, while some subfamilies, including G-LecRLKs-VIb, G-LecRLKs-VIII, G-LecRLKs-VII, G-LecRLKs-X, G-LecRLKs-III, L-LecRLKs-VI, L-LecRLKs-I, L-LecRLKs-II, L-LecRLKs-III and L-LecRLKs-V, were not found in the peanut (Tables 1 and 2). Polyploidy may cause an increase in the number of genome genes in the peanut. In recent research, a total of 309, 379, 467, 531, and 543 LRR-RLKs have been identified in diploid rice [34], diploid poplar [35], tetraploid soybean [36], allohexaploid wheat [37] and tetraploid cotton [38], respectively, indicating that larger gene families are present in polyploid plants. Other factors, including tandem duplication, segmental duplication, and exon 


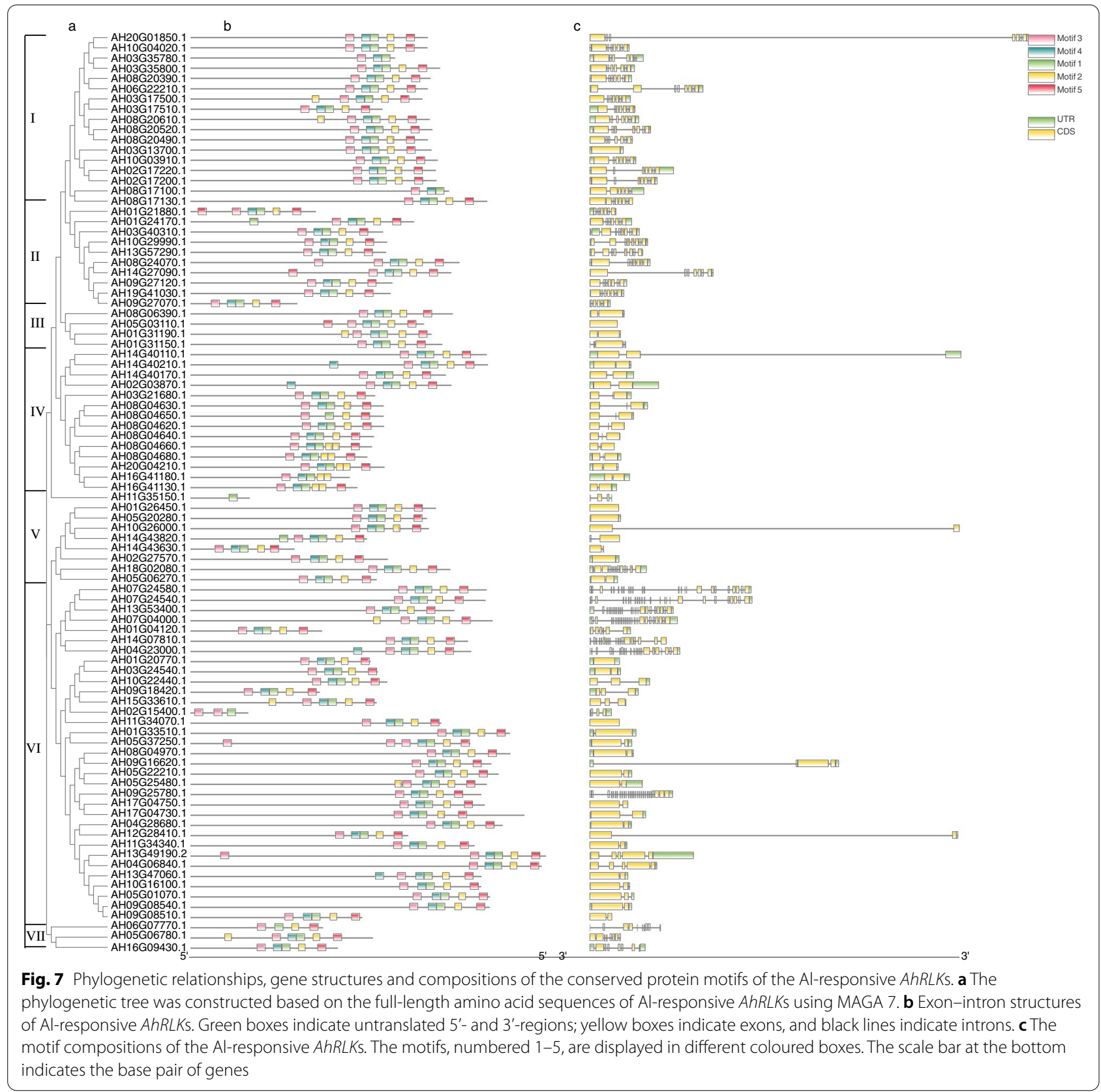

duplication and shuffling, also contribute to the expansion of gene families.

Gene duplication was the main mechanism for evolutionary events [39]. The gene duplication results revealed that $9.53 \%(125 / 1311)$ of $A h R L K \mathrm{~s}$ were located in regions with tandem duplications, and $61.78 \%(810 / 1311)$ were located in regions with segmental duplications, which indicated that segmental duplication played a major role in the evolution of AhRLKs (Additional file 5). Among the AhLRR-RLKs $5.66 \%(31 / 548)$ and $66.60 \%(365 / 548)$ were found to be located in the tandem duplication region and the segmental duplication region, respectively. This finding is consistent with the work in soybean that segmental duplication may be the main mechanism of LRR-RLK amplification [36]. In addition, the ka/ks ratios of $94.9 \%(1290 / 1360)$ of $A h R L K$ s were less than 1 , which suggested that most $A h R L K$ s were selected for purification (Fig. 5). The ka/ks ratios of six gene pairs including, AH16G29500.1 and AH16G29530.1, AH16G29500.1 and AH16G29560.1, AH08G17100.1 and AH18G07640.1, AH03G13490.1 and 


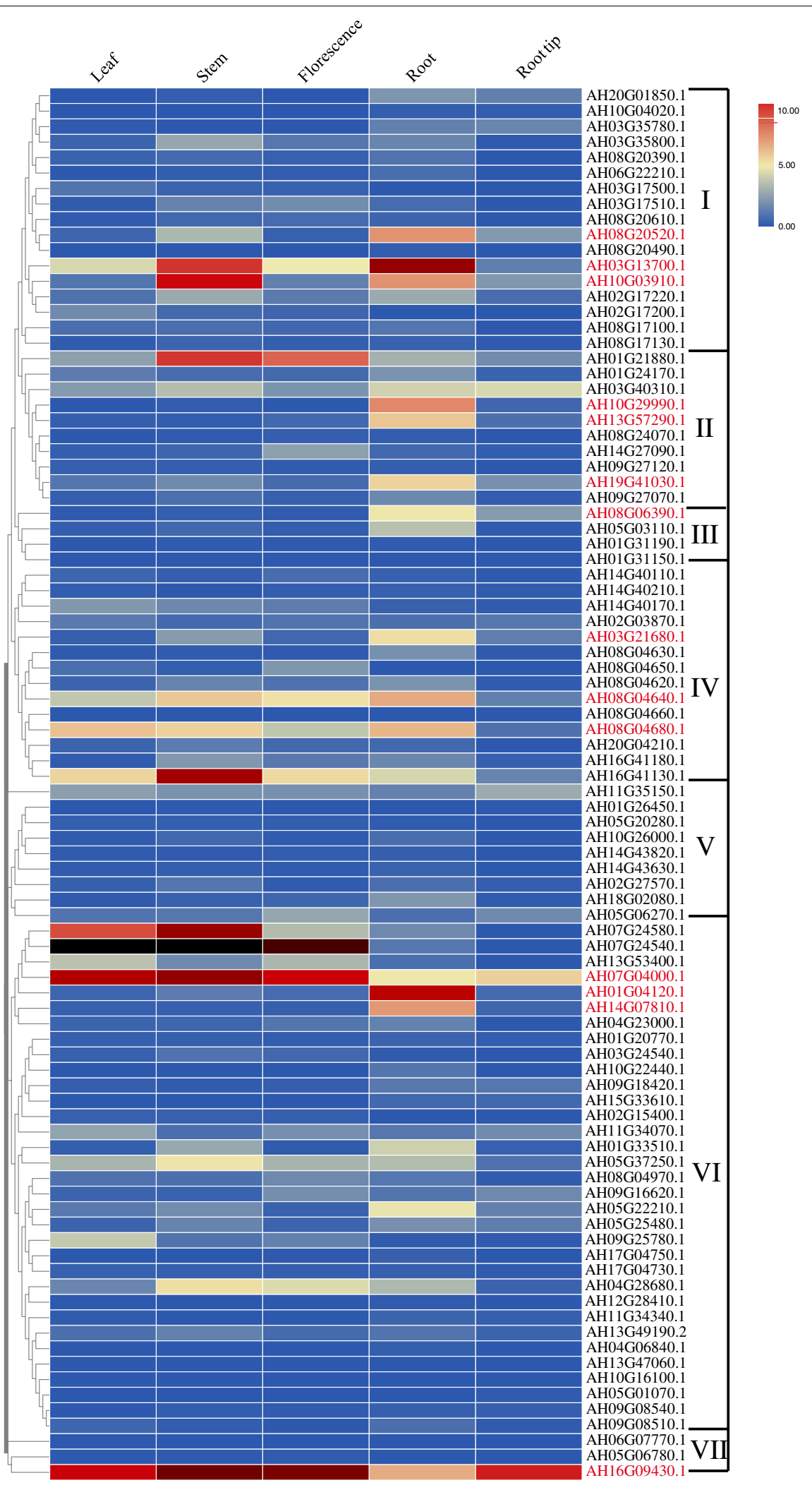

Fig. 8 Expression profiles of Al-responsive AhRLKs in different tissues. FPKM values were used to create the heat map with clustering. The scale represents the relative signal intensity of FPKM values 


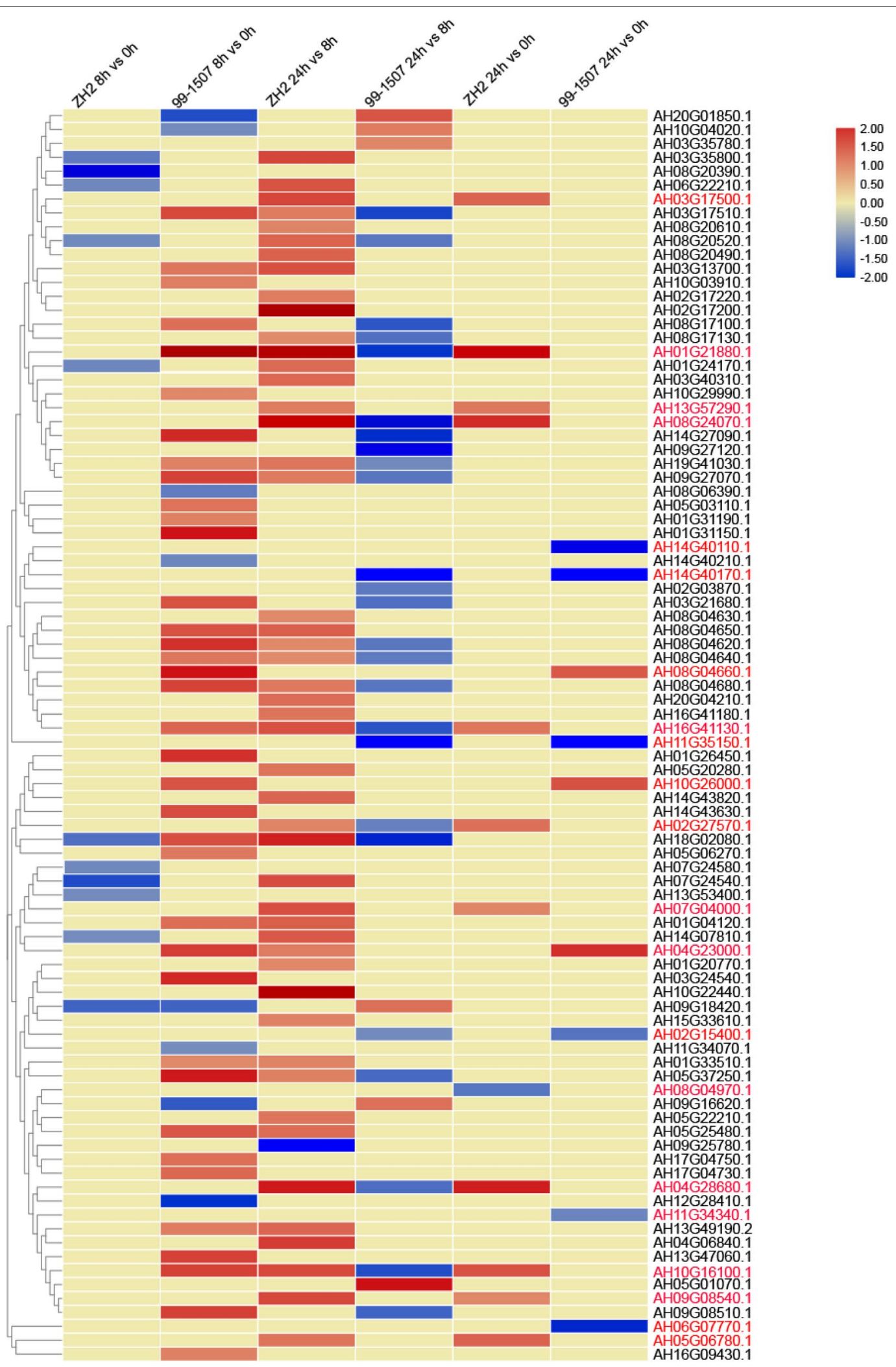

Fig. 9 Expression profiles of Al-responsive AhRLKs in the two varieties. The RNA-seq data of each gene in peanut root tips under Al stress in the two cultivars are shown here. Heatmap showed the log2-transformed ratio FPKM values. The genes were on the right of the expression bar 
Table 1 Total number of receptors distributed in the different subfamilies of LRR-RLKS

\begin{tabular}{|c|c|c|}
\hline \multirow[t]{2}{*}{ Subfamilies } & \multicolumn{2}{|c|}{ Plant species } \\
\hline & Peanut & A. thaliana \\
\hline LRR-I & 34 & 38 \\
\hline LRR-II & 27 & 13 \\
\hline LRR-III & 70 & 41 \\
\hline LRR-IV & 10 & 4 \\
\hline LRR-V & 1 & 9 \\
\hline LRR-VI-1 & 17 & 6 \\
\hline LRR-VI-2 & 9 & 4 \\
\hline LRR-VII & 9 & 8 \\
\hline LRR-VIII-1 & 18 & 7 \\
\hline LRR-VIII-2 & 32 & 12 \\
\hline LRR-IX & 3 & 4 \\
\hline LRR-X-a & 11 & 4 \\
\hline LRR-X-b & 6 & 9 \\
\hline LRR-XI & 74 & 29 \\
\hline LRR-XII & 61 & 9 \\
\hline LRR-XIII-a & 7 & 3 \\
\hline LRR-XIII-b & 4 & 3 \\
\hline LRR-XIV & 10 & 3 \\
\hline LRR-XV & 6 & 2 \\
\hline LRR-XVI & 5 & 1 \\
\hline LRR-XVII & 65 & 0 \\
\hline LRR-XVIII & 6 & 0 \\
\hline 1RR-XIX & 15 & 0 \\
\hline LRR-XX & 32 & 0 \\
\hline LRR-XXI & 2 & 0 \\
\hline LRR-XXII & 2 & 0 \\
\hline LRR-XXIII & 2 & 0 \\
\hline LRR-XXIV & 10 & 0 \\
\hline Total & 548 & 209 \\
\hline
\end{tabular}

AH13G15990.1, AH08G05340.1 and AH17G29130.1 and AH14G36690.1 and AH14G43630.1 were more than 1 , which indicated that these genes were in a state of positive selection in peanuts, evolving rapidly, and might be very important for the evolution of the peanut. We also calculated the divergence time, and the results showed that many tandem duplication events appeared to have occurred during relatively recent key periods 0-10 MYA, and many segmental duplication events appeared to have occurred during 0-30 MYA (Fig. 5b; Additional file 6), illustrating that these $A h R L K$ s were generated by recent gene duplication events in Arachis hypogaea L. Moreover, 28 gene transformation events were detected among the genes in the 52 tandem duplication clusters, and 44 genes involved in at least one gene conversion event, which
Table 2 Total number of receptors distributed in the different subfamilies of LecRLKs

\begin{tabular}{|c|c|c|}
\hline \multirow[t]{2}{*}{ Subfamilies } & \multicolumn{2}{|c|}{ Plant species } \\
\hline & Peanut & A. thaliana \\
\hline G-LecRKs-I & 16 & 2 \\
\hline G-LecRKs-II & 7 & 2 \\
\hline G-LecRKs-III & 0 & 2 \\
\hline G-LecRKs-IV & 2 & 2 \\
\hline G-LecRKs-V & 18 & 3 \\
\hline G-LecRKs-Vla & 29 & 2 \\
\hline G-LecRKs-Vlb & 0 & 3 \\
\hline G-LecRKs-VII & 0 & 5 \\
\hline G-LecRKs-VIII & 0 & 9 \\
\hline G-LecRKs-IX & 2 & 1 \\
\hline G-LecRKs-X & 0 & 1 \\
\hline G-LecRKs-XI & 37 & 0 \\
\hline G-LecRKs-XII & 2 & 0 \\
\hline G-LecRKs-XIII & 16 & 0 \\
\hline G-LecRKs-XIV & 6 & 0 \\
\hline G-LecRKs-XV & 9 & 0 \\
\hline G-LecRKs-XVI & 14 & 0 \\
\hline G-LecRKs-XVII & 10 & 0 \\
\hline G-LecRKs-XVIII & 9 & 0 \\
\hline G-LecRKs-XIX & 1 & 0 \\
\hline G-LecRKs-XX & 12 & 0 \\
\hline G-LecRKs-XXI & 15 & 0 \\
\hline L-LecRKs-I & 0 & 11 \\
\hline L-LecRKs-II & 0 & 2 \\
\hline L-LecRKs-III & 0 & 2 \\
\hline L-LecRKs-IV & 4 & 4 \\
\hline L-LecRKs-V & 0 & 9 \\
\hline L-LecRKs-VI & 0 & 4 \\
\hline L-LecRKs-VII & 15 & 3 \\
\hline L-LecRKs-VIII & 7 & 4 \\
\hline L-LecRKs-IX & 28 & 2 \\
\hline L-LecRKs-X & 4 & 1 \\
\hline L-LecRKs-XI & 1 & 0 \\
\hline L-LecRKs-XII & 6 & 1 \\
\hline L-LecRKs-XIII & 2 & 0 \\
\hline C-LecRKs & 2 & 1 \\
\hline Total & 274 & 76 \\
\hline
\end{tabular}

suggested that gene conversion events had taken place between the duplicated AhRLKs. Gene conversion is implicated in the concerted evolution of multigene families, which helps gene evolution by allowing more time for duplicated genes to obtain selectable differences [40, 41]. As changes in expression patterns are an important factor that cause genes to gain selectable differences $[40,42]$, studying the temporal 
and spatial expression patterns of these genes would be of interest.

\section{Conservation of the AhRLKs in response to Al stress}

In this study, a total of 90 AhRLKs were identified as $\mathrm{Al}$ stress-related genes, which were divided into 7 groups (Fig. 7). Most of the subgroups show certain regularity of exon-intron structure. For instance, all genes in subgroups I, II and VII contained more than three introns. Members belonging to the same subgroup had similar exon/intron organization. Furthermore, 5 conserved motifs were identified in these AhRLKs and the motif compositions among subgroups were consistent with the phylogenetic classification. These results indicated that the members in the subgroups were more conservative in the evolution.

\section{Diversity roles of Al-responsive AhRLKs in different subgroups}

To further understand the Al-responsive $A h R L K \mathrm{~s}$ in the peanut, we investigated the potential functions of each subgroup (Table 3). In subgroup I, PERK1 has been reported to regulate $A B A$ signalling pathways and modulate the expression of genes related to cell elongation and ABA signalling during root growth [43], implying that the genes in Subgroup I were essential to plant signalling and growth. The inhibition of root elongation is known to be the primary symptom of $\mathrm{Al}$ toxicity, and the members of subgroup I may take part in the $\mathrm{Al}$ response by influencing cell elongation. The genes known to function in subgroup II were reported to play a role in plant signal transduction, plant growth and biotic stress response, for instance, PXC1 and CRCK1 played a role in signal transduction [44, 45], PRK1 was essential for the postmeiotic development of pollen [46], FLS2 was involved in preinvasive immunity against bacterial infection [47], and $R C H 1$ was critical to the resistance of the hemibiotrophic fungal pathogen Colletotrichum higginsinaum [48]. In Subgroup III, ANXUR1/ ANXUR2 were involved in controlling pollen tube rupture during the fertilization process and regulating signal transduction [49]. FERONIA was required for cell elongation during vegetative growth [50], suggesting that the genes in subgroup III might play an important role in plant morphology. In subgroup IV, TMK1 was an essential enzyme for DNA synthesis in bacteria [51], which indicated that the genes of subgroup IV might play a critical role in cell expansion and proliferation regulation. The subgroup $\mathrm{V}$ gene $R L K 1$ was reported to increase tolerance to salinity, heavy metal stresses, and Botrytis cinerea infection [52], suggesting that the genes of subgroup $\mathrm{V}$ are implicated in biotic and abiotic stress responses. In subgroup VI, CRK5 was reported to respond to drought and salt stresses [53], and CRK45 was a potentially positive regulator of ABA signalling in early seedling growth [54] and stomatal movement [55], indicating that the genes of subgroup VI are critical to the abiotic stress response and related to plant morphology. The reported genes in subgroup VII, such as GsSRK, were shown to be positive regulators of plant tolerance to salt stress [56], and SD1-29 improved plant resistance to bacteria [57], showing that the genes of subgroup VII have critical roles in the response to biotic and abiotic stresses. In general, Al-responsive AhRLKs in different subgroups take part in the $\mathrm{Al}$ response by different pathways. Subgroups I and II are related to signal transduction, subgroup II is implicated in the biotic stress response, subgroups III and VI play an essential role in plant morphology, subgroup IV plays a critical role in cell expansion and proliferation regulation, and subgroups V and VII are critical to the biotic stress and abiotic stress response (Table 3 ).

The AtRLK gene family plays a role in plant growth and development processes [63]. As shown in the histograms in Fig. 8, the expression pattern of the Al-responsive $A h R L K s$ exhibited tissue specificity, and approximately $2.2 \%$ (2/90, AH07G04000.1 and $A H 16$ G09430.1) of Al-responsive AhRLKs were expressed in all four tested organs with high expression levels (value $>5$ ) in the peanut, implying that these genes might play essential roles in plant growth and development. Approximately 2.2\% (2/90, AH16G41130.1 and AH07G24540.1) of Al-responsive $A h R L K s$ were expressed specifically and at a high level in aerial organs. About 8.8\% (8/90, AH14G07810.1, AH03G21680.1 AH19G41030.1 AH13G57290.1, AH10G29990.1, AH08G20520.1, AH08G06390.1, and $A H 01 G 04120.1)$ of $\mathrm{Al}$-responsive $A h R L K \mathrm{~s}$ were expressed specifically and at a high level in roots or root tips. The tissue specificity of these Al-responsive $A h R L K \mathrm{~s}$ indicates their key roles in tissue development or tissue functions. Additionally, 6 tissue nonspecific genes (AH07G04000.1, AH03G13700.1, AH10G03910.1, AH08G04680.1, AH08G04640.1, and AH16G09430.1) that were expressed at a high level specifically in roots are also worth considering. As shown in the histograms in Fig. 9, the majority of the $\mathrm{Al}$-responsive $R L K \mathrm{~s}$ were upregulated after $8 \mathrm{~h}$ of $\mathrm{Al}$ treatment in $99-1507$, while only moderate changes were detected in some Al-responsive $R L K \mathrm{~s}$ in $\mathrm{ZH} 2$, which suggested that Al-responsive $R L K \mathrm{~s}$ responded rapidly to $\mathrm{Al}$ stress in the $\mathrm{Al}$-tolerant variety. Although the genes had different expression profiles under $\mathrm{Al}$ stress in different varieties, the expression levels of 12 genes (AH04G28680.1, AH16G41130.1, AH01G21880.1, AH10G16100.1, AH08G24070.1, 
Table 3 The classification of subgroups for Al responsive AhRLKs

\begin{tabular}{|c|c|c|c|c|}
\hline Subgroups & Gene ID & Gene Name & Reported & Function \\
\hline । & AH05G06780.1 & Proline-rich receptor-like protein kinase PERK4 & PERK1 & $\begin{array}{l}\text { responses to wounding and treatment with } \\
\text { salicylic acid and PERK1 mRNA accumulation } \\
\text { in response to these treatments shows a role in } \\
\text { plant defense signaling [43] }\end{array}$ \\
\hline$\|$ & AH09G18420.1 & $\begin{array}{l}\text { Leucine-rich repeat receptor-like protein kinase } \\
\text { PXC1 }\end{array}$ & PXC1 & $\begin{array}{l}\text { a regulator of secondary wall formation cor- } \\
\text { related with the TDIF-PXY/TDR-WOX4 signaling } \\
\text { pathway [44] }\end{array}$ \\
\hline$\|$ & AH01G04120.1 & $\begin{array}{l}\text { Calmodulin-binding receptor-like cytoplasmic } \\
\text { kinase } 1\end{array}$ & CRCK1 & $\begin{array}{l}\text { plays a role in stress signal transduction in plants } \\
\text { [45] }\end{array}$ \\
\hline$\|$ & AH13G53400.1 & $\begin{array}{l}\text { Probable LRR receptor-like serine/threonine- } \\
\text { protein kinase RKF3 }\end{array}$ & RKF1 & $\begin{array}{l}\text { regulates early flower primordia during stamen } \\
\text { development [58] }\end{array}$ \\
\hline$\|$ & $\begin{array}{l}\text { AH13G49190.2 } \\
\text { AH04G06840.1 }\end{array}$ & $\begin{array}{l}\text { LRR receptor-like serine/threonine-protein } \\
\text { kinase FLS2 }\end{array}$ & FLS2 & $\begin{array}{l}\text { involves in preinvasive immunity against bacterial } \\
\text { infection [59] }\end{array}$ \\
\hline$\|$ & AH02G15400.1 & Proline-rich receptor-like protein kinase PERK3 & PERK1 & $\begin{array}{l}\text { responses to wounding and treatment with } \\
\text { salicylic acid and PERK1 mRNA accumulation } \\
\text { in response to these treatments shows a role in } \\
\text { plant defense signaling [43] }\end{array}$ \\
\hline$\|$ & $\begin{array}{l}\text { AH01G20770.1 } \\
\text { AH03G24540.1 }\end{array}$ & Pollen receptor-like kinase 3 & PRK1 & $\begin{array}{l}\text { PRK1 is essential for postmeiotic development of } \\
\text { pollen [46] }\end{array}$ \\
\hline$\|$ & AH09G25780.1 & $\begin{array}{l}\text { LRR receptor-like serine/threonine-protein } \\
\text { kinase ERL1 }\end{array}$ & ERECTA & regulates elongation of above-ground organs [60] \\
\hline$\|$ & AH08G04970.1 & $\begin{array}{l}\text { LRR receptor-like serine/threonine-protein } \\
\text { kinase } \mathrm{RCH} 1\end{array}$ & $\mathrm{RCH} 1$ & $\begin{array}{l}\text { resistances to the hemibiotrophic fungal patho- } \\
\text { gen colletotrichum higginsianum [48] }\end{array}$ \\
\hline$\|$ & AH09G16620.1 & $\begin{array}{l}\text { Leucine-rich repeat receptor-like protein kinase } \\
\text { PXL1 }\end{array}$ & PXL1 & $\begin{array}{l}\text { regulates signal transduction pathways under } \\
\text { temperature fluctuations [61] }\end{array}$ \\
\hline$\|$ & AH05G37250.1 & $\begin{array}{l}\text { Leucine-rich repeat receptor-like tyrosine-pro- } \\
\text { tein kinase PXC3 }\end{array}$ & PXC1 & $\begin{array}{l}\text { a regulator of secondary wall formation cor- } \\
\text { related with the TDIF-PXY/TDR-WOX4 signaling } \\
\text { pathway [44] }\end{array}$ \\
\hline$\|$ & AH05G22210.1 & $\begin{array}{l}\text { LRR receptor-like serine/threonine-protein } \\
\text { kinase HSL2 }\end{array}$ & HSL2 & $\begin{array}{l}\text { involves in Floral organ abscission and lateral root } \\
\text { emergence [62] }\end{array}$ \\
\hline$\|$ & AH05G25480.1 & Receptor-like protein kinase HSL1 & HSL1 & $\begin{array}{l}\text { participates in the Repression of Seed Maturation } \\
\text { Genes in Arabidopsis Seedlings [63] }\end{array}$ \\
\hline$\|$ & AH02G27570.1 & $\begin{array}{l}\text { Probable LRR receptor-like serine/threonine- } \\
\text { protein kinase RKF3 }\end{array}$ & RKF1 & $\begin{array}{l}\text { regulates early flower primordia during stamen } \\
\text { development [58] }\end{array}$ \\
\hline III & AH01G26450.1 & Receptor-like protein kinase ANXUR1 & ANXUR1/ANXUR2 & $\begin{array}{l}\text { control pollen tube rupture during the fertilization } \\
\text { process in A. thaliana [49] }\end{array}$ \\
\hline III & $\begin{array}{l}\text { AH10G26000.1 } \\
\text { AH14G43820.1 } \\
\text { AH05G20280.1 }\end{array}$ & Receptor-like protein kinase FERONIA & FERONIA & $\begin{array}{l}\text { affects plant reproduction, development, and } \\
\text { stress tolerance [50] }\end{array}$ \\
\hline III & AH05G06270.1 & LysM domain receptor-like kinase 4 & RLK1 & $\begin{array}{l}\text { activates defense and Abiotic-Stress Responses } \\
\text { [52] }\end{array}$ \\
\hline III & AH14G43630.1 & Receptor-like protein kinase ANXUR2 & ANXUR1/ANXUR2 & $\begin{array}{l}\text { control pollen tube rupture during the fertilization } \\
\text { process in Arabidopsis thaliana [49] }\end{array}$ \\
\hline III & AH11G35150.1 & $\begin{array}{l}\text { LRR receptor-like serine/threonine-protein } \\
\text { kinase HSL2 }\end{array}$ & HSL2 & $\begin{array}{l}\text { involved in Floral organ abscission and lateral root } \\
\text { emergence [62] }\end{array}$ \\
\hline IV & AH02G03870.1 & Receptor protein kinase TMK1 & TMK1 & $\begin{array}{l}\text { an essential enzyme for DNA synthesis in bacteria, } \\
\text { phosphorylating deoxythymidine monophos- } \\
\text { phate (dTMP) to deoxythymidine diphosphate } \\
\text { (dTDP), and thus is a potential new antibacterial } \\
\text { drug target [51] }\end{array}$ \\
\hline V & $\begin{array}{l}\text { AH01G31190.1 } \\
\text { AH01G31150.1 }\end{array}$ & $\begin{array}{l}\text { G-type lectin S-receptor-like serine/threonine- } \\
\text { protein kinase RLK1 isoform X2 }\end{array}$ & RLK1 & $\begin{array}{l}\text { activates defense and Abiotic-Stress Responses } \\
\text { [52] }\end{array}$ \\
\hline $\mathrm{VI}$ & $\begin{array}{l}\text { AHO9G27120.1 } \\
\text { AH19G41030.1 }\end{array}$ & Cysteine-rich receptor-like protein kinase 29 & CRK45/CRK5 & $\begin{array}{l}\text { response to abscisic acid and abiotic stressesa } \\
\text { potentially positive regulator of ABA signaling in } \\
\text { early seedling growth, stomatal movement and } \\
\text { plant drought tolerance }[53,54]\end{array}$ \\
\hline
\end{tabular}


Table 3 (continued)

\begin{tabular}{|c|c|c|c|c|}
\hline Subgroups & Gene ID & Gene Name & Reported & Function \\
\hline $\mathrm{VI}$ & $\begin{array}{l}\text { AH08G24070.1 } \\
\text { AH14G27090.1 }\end{array}$ & Cysteine-rich receptor-like protein kinase 25 & CRK45/CRK5 & $\begin{array}{l}\text { response to abscisic acid and abiotic stresses, a } \\
\text { potentially positive regulator of } A B A \text { signaling in } \\
\text { early seedling growth, stomatal movement and } \\
\text { plant drought tolerance }[53,54]\end{array}$ \\
\hline $\mathrm{VI}$ & $\begin{array}{l}\text { AH10G29990.1 } \\
\text { AH13G57290.1 } \\
\text { AH09G27070.1 }\end{array}$ & Cysteine-rich receptor-like protein kinase 10 & CRK45/CRK5 & $\begin{array}{l}\text { response to abscisic acid and abiotic stresses, a } \\
\text { potentially positive regulator of ABA signaling in } \\
\text { early seedling growth, stomatal movement and } \\
\text { plant drought tolerance }[53,54]\end{array}$ \\
\hline $\mathrm{VI}$ & AH03G40310.1 & Cysteine-rich receptor-like protein kinase 2 & CRK45/CRK5 & $\begin{array}{l}\text { response to abscisic acid and abiotic stresses, a } \\
\text { potentially positive regulator of } A B A \text { signaling in } \\
\text { early seedling growth, stomatal movement and } \\
\text { plant drought tolerance }[53,54]\end{array}$ \\
\hline VII & AH10G03910.1 & $\begin{array}{l}\text { G-type lectin S-receptor-like serine/threonine- } \\
\text { protein kinase B120 }\end{array}$ & GSSRK & $\begin{array}{l}\text { a positive regulator of plant tolerance to salt stress } \\
\text { [56] }\end{array}$ \\
\hline VII & $\begin{array}{l}\text { AH2OG01850.1 } \\
\text { AH10G04020.1 } \\
\text { AH06G22210.1 }\end{array}$ & $\begin{array}{l}\text { Receptor-like serine/threonine-protein kinase } \\
\text { SD1-8 }\end{array}$ & SD1-29 & resistances to bacteria in crop species [64] \\
\hline VII & AH01G24170.1 & $\begin{array}{l}\text { G-type lectin S-receptor-like serine/threonine- } \\
\text { protein kinase B120 }\end{array}$ & GsSRK & $\begin{array}{l}\text { a positive regulator of plant tolerance to salt stress } \\
\text { [56] }\end{array}$ \\
\hline
\end{tabular}

Note: only the Al responsive AhRLKs with characterized homologs were listed in the table

$\begin{array}{lcc}\text { AH02G27570.1, AH07G04000.1, } & \text { AH09G08540.1, } \\ \text { AH13G57290.1, AH03G17500.1, } & \text { AH05G06780.1, } \\ \text { and AH08G04970.1) and 9 genes } & (A H 04 G 23000.1, \\ \text { AH11G34340.1, AH06G07770.1, } & \text { AH14G40110.1, } \\ \text { AH10G26000.1, AH02G15400.1, } & \text { AH11G35150.1, } \\ \text { AH14G40170.1, AH08G04660.1), which reached }\end{array}$ their peak in $24 \mathrm{~h}$ vs $0 \mathrm{~h} \mathrm{Al}$-treatment comparison in $\mathrm{ZH} 2$ and 99-1507, implying important roles in Al stress responses. Among them, AH01G21880.1 and $A H 04 G 28680.1$ were expressed at a high level in stems, implying their potential roles in regulating the growth of stems. AH13G57290.1 was expressed specifically and at a high level in roots, implying its critical roles in mediating the $\mathrm{Al}$ response in peanut. AH07G04000.1 was expressed in all four tested organs with high expression levels, and it might play essential roles in plant growth and development under $\mathrm{Al}$ stress. Taken together, our results revealed that 13 genes (AH11G35150.1, AH08G24070.1, AH13G57290.1, AH02G27570.1, AH05G06780.1, AH02G15400.1, AH01G35150.1, AH14G27090.1, AH05G37250.1, AH10G03910.1, AH19G41030.1, AH10G29990.1, and AH10G26000.1), whose homologues have been reported to be involved in early seedling growth regulation, early flower primordia and stamen development, lateral root emergence, abiotic stress responses and plant defence signalling in Arabidopsis thaliana, were important $\mathrm{Al}$-responsive genes that may be suitable candidates for interpreting the mechanisms underlying the $\mathrm{Al}$ response in peanuts in future work.

\section{Conclusions}

In this study, a total of 1311 RLKs were identified in the peanut genome, 2 times the number of Arabidopsis RLKs, including 548 LRR-RLKs and 274 LecRLKs. LRRRLK represented the largest RLK gene family identified in plants. These $A h R L K s$ were unevenly distributed among 20 chromosomes of peanut. Compared with tandem duplication, segmental duplication might play a more critical role in some $A h R L K$ s. Furthermore, we identified a total of $90 \mathrm{Al}$-responsive AhRLKs by mining the transcriptome database. The exon/intron compositions and motif arrangements were considerably conserved among members in the same groups or subgroups. Analysis of transcriptome data revealed tissue expression patterns of the 90 Al-responsive $A h R L K \mathrm{~s}$, and tissue-specific expression genes were found. Among them, root-specific genes might play a key role in $\mathrm{Al}$ sensing and response in the peanut. The close phylogenetic relationship of $\mathrm{Al}$ responsive AhRLKs and characterized AhRLKs in the same subgroup provided insight into their putative functions. Overall, this systematic analysis provided valuable information to understand the biological functions of the AhRLK genes under $\mathrm{Al}$ stress in peanut.

\section{Methods}

\section{The resources of peanut AhRLKs}

All RLK full-length amino acid sequences in Arabidopsis were downloaded from UniProt (https://www.unipr ot.org/) and these sequences were used as queries to perform a BLASTP search against $A$. duranensis RLKs 
by NCBI (https://www.ncbi.nlm.nih.gov/). These resulting sequences were then used as new queries to conduct a BLASTP search again in PEANUT GENOME RESOURSE (http://peanutgr.fafu.edu.cn/), to avoid missing potential members. The redundant entries were removed manually. Then the resulting unique sequences were analysed with both SMART (http://smart.emblheidelberg.de) [65] and NCBI's Conserved Domains Database (CDD; http://www.ncbi.nlm.nih.gov/Struc ture/cdd/wrpsb.cgi) to ensure the presence of the RLK domains in newly identified members. Only proteins containing at least one kinase domain were considered putative AhRLKs, and 1311 AhRLKs were finally obtained. The amino acid residue base, and molecular weight were predicted with ExPaSy ProtParam tool (https:// web.expasy.org/protparam/). The genome sequence, protein sequences and genome annotation of the peanut were performed according to PEANUT GENOME RESOURSE (http://peanutgr.fafu.edu.cn/).

\section{Multiple sequence alignments and phylogenetic tree construction of AhRLKs}

The full-length amino acid sequences of LRR-AhRLKs, LecRLKs and $90 \mathrm{Al}$-responsive AhRLKs defined in the previous section were aligned using ClustalX in MEGA 7 with default parameters [66]. The phylogenetic tree based on the multiple sequence alignments of peanut LRR-RLKs (Fig. 1), LecRLKs (Fig. 2) and 90 AhRLKs in response to $\mathrm{Al}$ stress (Fig. 6) was generated by MEGA 7. A Poisson correction model was used to account for multiple substitutions, while alignment gaps were removed with partial deletion. The statistical strength was estimated by bootstrap resampling using 1000 replicates. Based on the multiple sequence alignment and the previously reported classification of Arabidopsis thaliana, the peanut $R L K \mathrm{~s}$ were assigned to different subfamilies and subgroups [24, 67].

\section{Chromosomal locations and duplication analysis for peanut $R L K s$}

The physical location of AhRLKs on the chromosomes was obtained from the PEANUT GENOME RESOURSE database (http://peanutgr.fafu.edu.cn/). All members of $A h R L K$ s were mapped onto peanut chromosomes based on their physical positions, and chromosomal location images were produced with the online software Map Gene 2 Chromosome v2 (MG2C:http://mg2c.iask.in/ mg2c_v2.0/). The chromosome location information of the peanut was extracted from GFF files that contain the information of peanut genome annotation. BLASTP was performed to search for potential homologous gene pairs $\left(E-\right.$ value $<1 \mathrm{e}^{-5}$ ) across genomes. Information on homologous pairs was used as input to identify syntenic chains by MCScanX [68]. In addition, MCScanX was also used to identify tandem and segmental duplications in the $A h R L K$ gene family. RLKs clustered together within $100 \mathrm{~kb}$ were regarded as tandem duplicated genes based on the criteria of other plants. The diagram was generated by TBtools [69]. The nonsynonymous (Ka) and synonymous (Ks) substitution ratios were calculated by Simple Ka/Ks Caculator in TBtools. The divergence time was calculated with the formula $\mathrm{T}=\mathrm{Ks} / 2 \mathrm{r}$, and the $\mathrm{r}$ of dicotyledonous plants was $1.5^{*} 10^{\wedge}-8$ synonymous substitutions per site per year [70]. We used the Geneconv program with default parameters to search evidence for tandem duplication cluster gene conversion (http://www. math.wustl.edu/ sawyer/geneconv/) [71]. Since GENECONV required at least three sequences for detecting gene conversion events, tandem duplication clusters that contained at least 3 genes were detected. For this program, the clustalW (CDS) alignment was used as the input. Geneconv can detect candidate fragments of directed gene conversion between gene pairs (allowing mismatch). Gene conversion events were considered as statistically significant when $P<0.05$.

\section{Gene structure and motif analysis of $A h R L K s$ in response to Al stress}

The exon-intron structures of 90 peanut Al-responsive AhRLKs were determined based on their coding sequence alignments and their respective genomics sequences, while diagrams were obtained from the online program Gene Structure Display Server with default parameters (http://gsds.cbi.pku.edu.cn/) [72]. To identify the conserved motifs of the $\mathrm{Al}$ response AhRLKs, the MEME (Multiple Em for Motif Elicitation) tool was used to predict putative motifs of these proteins (http://memesuite.org/) [73]. The combination of phylogenetic tree, gene and protein structures was generated using TBtools.

\section{Expression Pattern Analysis for Al-responsive AhRLKs}

By scrutinizing the existing transcriptome data, the expression profiles of Al-responsive AhRLKs in different tissues under normal conditions and in the root tips of different peanut varieties under $\mathrm{Al}$ stress were analysed. The raw RNA-seq reads in five tissues, including leaf, stem, florescence, root and root tips, were available at Peanut Genome Resource (http://peanutgr.fafu.edu. $\mathrm{cn} /$ ). The RNA-seq data of ZH2 (ZhongHua No.2, Al sensitive) and 99-1507 (Al tolerant) under $\mathrm{Al}$ treatment were deposited in the database of the National Center for Biotechnology Information (NCBI) under accession number PRJNA525247 (https://www.ncbi.nlm.nih.gov/ sra/PRJNA525247). Heat maps of the Log2-transformation ratio of FPKM values and gene FPKM values in 


\section{Al-responsive $A h R L K s$ of different varieties or tissues were visualized using TBtools.}

\begin{abstract}
Abbreviations
Ah: Arachishypogaea.L; Al: Aluminum; At: Arabidopsis thaliana; EGF-RLK: Epidermal growth factor like RLK; LecRLK: Lectin-like RLK; LRR-RLK: Leucine-Rich Repeat RLK; PCD: Programmed Cell Death; PR5K-RLK: Pathogenesis related protein-5 like receptor kinases RLK; MEME: Multiple Em for Motif Elicitation; ML: Maxinum Likehood; RLK: Receptor-like protein Kinase; S-RLK: S-domain RLK; TNFR-RLK: Tumor-necrosis factor receptor-like RLK; WAK1: Cell wall-associated receptor kinase 1.
\end{abstract}

\section{Supplementary Information}

The online version contains supplementary material available at https://doi. org/10.1186/s12870-021-03031-4.

Additional file 1: Complete list and classification of 1311 AhRLKs in peanut.

Additional file 2: Complete list and classification of Al response AhRLKs in peanut.

Additional file 3: Subfamily and chromosome distribution of AhLRR-RLKs in peanut.

Additional file 4: Subfamily and chromosome distribution of AhLecRLKs in peanut.

Additional file 5: Tandem duplication clusters of AhRLKs.

Additional file 6: Devergence time among AhRLKs tandem duplication pairs and segmental duplication pairs.

Additional file 7: Tandom duplicated genes analyzed for gene conversion.

Additional file 8: The motif of Al stress-related AhRLKs.

Additional file 9: Expression Profiles of Al-responsive AhRLKs under Al stress.

\section{Acknowledgements}

We thank Miss Xia Li and Miss Li Wei developed the biological experiments for the transcriptome sequencing.

\section{Authors' contributions}

DX and LFH conceived the experiments. DX and XW designed the experiments. XW, MHW and RLH performed the data analysis, XW, DX wrote the manuscript. DX, XW, LFH, AQW and J Z revised this manuscript. All authors read and approved the final manuscript.

\section{Funding}

This work was supported by the National Natural Science Foundation of China (Grant No. 31701356, 31860334). Apart from providing financial support, funding bodies were not involved in the study design, data analyses, and interpretation of results or manuscript preparation.

\section{Availability of data and materials}

The datasets generated and analyzed during the current study are available from the corresponding author on reasonable request. The two peanut cultivars that had used to generate the RNA-seq data with Al treatment were kindly provided by Prof. Bo-shou Liao from the Oil Crop Research Institute, Chinese Academy of Agricultural Sciences (CAAS), and they were routinely planted on the farm of Guangxi University in Nanning, Guangxi Province, China and identified by Prof. He. In detail, ZhongHua No. 2 (ZH2) (85-007, CHINA PEANUNT DATA CENTEI, http://www.peanutdata.cn/variety/index.htm) has been used widely in agriculture practice while 99-1507 has not been approved for commercial use. The RNA-seq data of ZH2 and 99-1507 under Al treatment had been deposited in the database of the National Center for Biotechnology Information (NCBI) under accession number PRJNA525247 (https://www.ncbi.nlm.nih.gov/sra/PRJNA525247). The raw RNA-seq reads in different tissues and AhRLKs sequences are available at Peanut Genome Resource (http://peanutgr.fafu.edu.cn/).

\section{Declarations}

Ethics approval and consent to participate

Not applicable.

\section{Consent for publication}

Not applicable.

\section{Competing interests}

The authors declare that they have no competing interests.

\section{Author details}

${ }^{1}$ National Demonstration Center for Experimental Plant Science Education, College of Agriculture, Guangxi University, Nanning 530004, China. ${ }^{2}$ Guangxi Key Laboratory for Agro-Environment and Agro-Product Safety, Nanning 530004, China. ${ }^{3}$ Key Laboratory of Crop Cultivation and Tillage, GuangxiColleges and Universities, Nanning 530004, China.

Received: 5 July 2020 Accepted: 11 May 2021

Published online: 21 June 2021

\section{References}

1. Uexküll HRV, Mutert E. Global extent, development and economic impact of acid soils. Plant Soil. 1995:171(1):1-15.

2. Sade H, Meriga B, Surapu V, Gadi J, Sunita MSL, Suravajhala P, Kishor PBK Toxicity and tolerance of aluminum in plants: tailoring plants to suit to acid soils. Biometals. 2016;29(2):187-210

3. Matsumoto $\mathrm{H}$, Motoda $\mathrm{H}$. Aluminum toxicity recovery processes in root apices. Possible association with oxidative stress. Plant Sci. 2012;185-186:1-8.

4. Yao S, Huang W, Pan C, Zhan J, He LF. Caspase-like proteases regulate aluminum-induced programmed cell death in peanut. Plant Cell Tissue Organ Cult. 2016;127(3):1-13.

5. He H-Y, Gu M-H, He L-F. Signaling Pathways of Aluminum-Induced Programmed Cell Death in Higher Plants. In: Panda SK, Baluška F, editors. Aluminum Stress Adaptation in Plants. Cham: Springer International Publishing: 2015. p. 63-80.

6. Daneva A, Gao Z, Van DM, Nowack MK. Functions and regulation of programmed cell death in plant development. Ann Rev Cell Dev Biol. 2016;32(1):111315-24915

7. Yamamoto YHAMH. Oxidative Damage to Membranes by a Combination of Aluminum and Iron. Plant Cell Physiol. 1997;38(12):1333-9.

8. Rath I, Barz W. The role of lipid peroxidation in aluminium toxicity in soybean cell suspension cultures. Z Naturforsch C J Biosci. 2000:55(11-12):957-64.

9. Boscolo PRS, Menossi M, Jorge RA. Aluminum-induced oxidative stress in maize. Phytochemistry. 2003;62(2):181-9.

10. Tamás L, Budíková S, Huttová J, Mistrík I, Šimonovičová M, Široká B. Aluminum-induced cell death of barley-root border cells is correlated with peroxidase- and oxalate oxidase-mediated hydrogen peroxide production. Plant Cell Rep. 2005;24(3):189-94.

11. Yakimova ET, Kapchinatoteva VM, Woltering EJ. Signal transduction events in aluminum-induced cell death in tomato suspension cells. J Plant Physiol. 2007;164(6):702-8.

12. Jie Z, Kou RJ, Chuang-Zhen LI, Hu-Yi HE, Long-Fei AH, University G. Nanning: effects of aluminum on physiological characteristics of mitochondrial membrane in peanut root tips. Acta Agron Sin. 2009;35(6):1059-67.

13. Yuan N, Rai KM, Balasubramanian VK, Upadhyay SK, Luo H, Mendu V. Genome-wide identification and characterization of LRR-RLKs reveal functional conservation of the SIF subfamily in cotton ( Gossypium hirsutum ). Bmc Plant Biol. 2018;18(1):185.

14. Giranton JLDCCJ. The integral membrane S-locus receptor kinase of Brassica has serineythreonine kinase activity in a membranous environment and spontaneously forms oligomers in planta. Proc Natl Acad Sci USA. 2000;7(97):3759-64. 
15. Deeken R, Kaldenhoff R. Light-repressible receptor protein kinase: a novel photo-regulated gene from Arabidopsis thaliana. Planta. 1997:202(4):479-86.

16. Clark SE WRME, Clark SE, Williams RW, Meyerowitz EM. The CLAVATA1 gene encodes a putative receptor kinase that controls shoot and floral meristem size in Arabidopsis. Cell. 1997:89:575-85.

17. Kline KGCMJ. In planta changes in protein phosphorylation induced by the plant hormone abscisic acid. P Natl Acad Sci Usa. 2010;107(36):15986-91.

18. Chen KDLCZ. Sensitization of defense responses and activation of programmed cell death by a pathogen-induced receptor-like protein kinase in Arabidopsis. Plant Mol Biol. 2003;53:61-74.

19. Pitorre D, Llauro C, Jobet E, Guilleminot J, Brizard JP, Delseny M, Lasserre E. RLK7, a leucine-rich repeat receptor-like kinase, is required for proper germination speed and tolerance to oxidative stress in Arabidopsis thaliana. Planta. 2010;232(6):1339-53.

20. Feng Y, Zhu CS, Pang BP. Advance in research of plant receptor-like protein kinases. Acta Botan Boreali-Occiden Sin. 2009;4:851-8.

21. Stone JM, Walker JC. Plant protein kinase families and signal transduction. Plant Physiol. 1995;108(2):451-7.

22. Lally D, Ingmire P, Tong HY, He ZH. Antisense expression of a cell wallassociated protein kinase, WAK4, inhibits cell elongation and alters morphology. Plant Cell. 2001;13(6):1317-31.

23. Mayandi S, Bunichi E, Zheng-Hui H, Hongyun T, Hiroki O, Frantisek B,

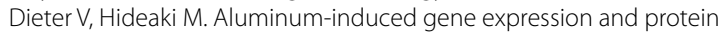
localization of a cell wall-associated receptor kinase in Arabidopsis. Plant Physiol. 2003;132(4):2256-66.

24. Teixeira MA, Rajewski A, He J, Castaneda OG, Litt A, Kaloshian I. Classification and phylogenetic analyses of the Arabidopsis and tomato G-type lectin receptor kinases. BMC Genomics. 2018;19(1):239.

25. Bouwmeester K, Govers F. Arabidopsis L-type lectin receptor kinases: phylogeny, classification, and expression profiles. J Exp Bot. 2009;60(15):4383-96

26. Zhuang W, Chen $\mathrm{H}$, Yang M, Al E. The genome of cultivated peanut provides insight into legume karyotypes, polyploid evolution and crop domestication. NAT GENET. 2019;5(51):865-76.

27. Leister D. Tandem and segmental gene duplication and recombination in the evolution of plant disease resistance genes. Trends Genet. 2004;20(3):116-22.

28. Koch MA, Bernhard $H$, Thomas M. Comparative evolutionary analysis of chalcone synthase and alcohol dehydrogenase loci in arabidopsis, arabis, and related genera (Brassicaceae). Mole Biol Evol. 2000;17(10):1483-98.

29. Dong X, Xia L, YunYi Z. Transcriptome analysis reveals significant difference in gene expression and pathways between two peanut cultivars under al stress. Gene. 2021;781:145535.

30. Yu J WJLW. The genomes of Oryza sativa: the genomes of Oryza sativa: a history of duplications. PLOS Biol. 2005:2(3):266-81.

31. Jiangmei S, Leiting L, Peng W, Shaoling Z, Juyou W. Genome-wide characterization, evolution, and expression analysis of the leucine-rich repeat receptor-like protein kinase (LRR-RLK) gene family in Rosaceae genomes. BMC Genomics. 2017:18(1):763.

32. Lease K, Ingham E, Walker JC. Challenges in understanding RLK function. Curr Opin Plant Biol. 1998;1(5):388-92.

33. Sun X. Xa26, a gene conferring resistance to Xanthomonas oryzae pv. oryzae in rice, encodes an LRR receptor kinase-like protein. Plant J. 2004;37(4):517-27.

34. Xinli S, Guo-Liang W. Genome-wide identification, characterization and phylogenetic analysis of the rice LRR-kinases. PLoS One. 2011;6(3):e16079.

35. Wang YZJY. Genome-wide identification, characterization and expression analysis of populus leucine-rich repeat receptor-like protein kinase genes. BMC Genomics. 2013;318(14):318.

36. Zhou F, Guo Y, Qiu L. Genome-wide identification and evolutionary analysis of leucine-rich repeat receptor-like protein kinase genes in soybean. BMC Plant Biol. 2016:16(1):58.

37. Shumayla, Shailesh S, Rohit K, Venugopal M, Kashmir S, Upadhyay SK. Genomic dissection and expression profiling revealed functional divergence in triticum aestivum leucine rich repeat receptor like kinases (TaLRRKs). Front Plant Sci. 2016;7:1374

38. Ning Y, Mohan RK, Kumar BV, Kumar US, Hong L, Venugopal M. Genomewide identification and characterization of LRR-RLKs reveal functional conservation of the SIF subfamily in cotton (Gossypium hirsutum). BMC Plant Biol. 2018;18(1):185.

39. Guo YL. Gene family evolution in green plants with emphasis on the origination and evolution of Arabidopsis thaliana genes. Plant J Cell Mole Biol. 2012;73(6):941-51.

40. Walsh JB. How often do duplicated genes evolve new functions? Genetics. 1995;139(1):421-8.

41. Hanikenne M, Kroymann J, Trampczynska A, Bernal M, Motte P, Clemens S, Krämer U. Hard selective sweep and ectopic gene conversion in a gene cluster affording environmental adaptation. PLoS Genet. 2013;9(8):e1003707

42. Rourke I J EPD. Evidence for gene conversion between tandemly duplicated cytoplasmic actin genes of Helicoverpa armigera (Lepidoptera:Noctuidae). J Mole Evol. 1997:44(2):169-77.

43. Silva NF, Goring DR. The proline-rich, extensin-like receptor kinase-1 (PERK1) gene is rapidly induced by wounding. Plant Mol Biol. 2002;50(4-5):667-85.

44. Wang J, Kucukoglu M, Zhang L, Chen P, Decker D, Nilsson O, Jones B, Sandberg G, Zheng B. The Arabidopsis LRR-RLK, PXC1, is a regulator of secondary wall formation correlated with the TDIF-PXY/TDR-WOX4 signaling pathway. BMC Plant Biol. 2013;13(1):94.

45. Yang T, Chaudhuri S, Yang L, Chen Y, Poovaiah BW. Calcium/calmodulin up-regulates a cytoplasmic receptor-like kinase in plants. J Biol Chem. 2004:279(41):42552-9.

46. Lee HS, Karunanandaa B, Mccubbin A, Gilroy S, Kao TH. PRK1, a receptorlike kinase of Petunia inflata, is essential for postmeiotic development of pollen. Plant J. 2003;9(5):613-24.

47. Li L, Li M, Yu L, Zhou Z, Liang X, Liu Z, Cai G, Gao L, Zhang X, Wang Y. The FLS2-associated kinase BIK1 directly phosphorylates the NADPH oxidase RbohD to control plant immunity. Cell Host Microbe. 2014;15(3):329-38.

48. Narusaka Y, Narusaka M, Park P, Kubo Y, Hirayama T, Seki M, Shiraishi T, Ishida J, Nakashima M, Enju A. RCH1, a locus in Arabidopsis that confers resistance to the hemibiotrophic fungal pathogen colletotrichum higginsianum. Mole Plant Microbe Interact. 2004;17(7):749-62.

49. Du S, Qu LJ, Xiao J. Crystal structures of the extracellular domains of the CrRLK1L receptor-like kinases ANXUR1 and ANXUR2. Protein Sci. 2018;27(4):886-92.

50. David C, Yunqing Y, Assmann SM. A kinase-dead version of FERONIA receptor-like kinase has dose-dependent impacts on rosette morphology and RALF1-mediated stomatal movements. FEBS Lett. 2018;592(20):3429-37.

51. Martínez-Botella G, Loch JT, Green OM, Kawatkar SP, Olivier NB, BoriackSjodin PA, Keating TA. Sulfonylpiperidines as novel, antibacterial inhibitors of Gram-positive thymidylate kinase (TMK). Bioorg Med Chem Lett. 2013;23(1):169-73.

52. YarivBrotman USJL. The lysm receptor-like kinase LysM RLK1 Is required to activate defense and abiotic-stress responses induced by overexpression of fungal chitinases in arabidopsis plants. Mol Plant. 2012;5:1113-24.

53. Lu K, Liang S, Wu Z, Bi C, Yu YT, Ma Y, Wang XF, Zhang DP. Overexpression of an Arabidopsis cysteine-rich receptor-like protein kinase, CRK5, enhances abscisic acid sensitivity and confers drought tolerance. J Exp Bot. 2016;67(17):5009-27.

54. Zhang X, Yang G, Shi R, Han X, Qi L, Wang R, Xiong L, Li G. Arabidopsis cysteine-rich receptor-like kinase 45 functions in the responses to abscisic acid and abiotic stresses. Plant Physiol Biochem. 2013;67(67C):189-98.

55. Zhang X, Guanyu Y, Rui S, Xiaomin H, Liwang Q, Ruigang W, Xiong L, Guojing L. Arabidopsis cysteine-rich receptor-like kinase 45 functions in the responses to abscisic acid and abiotic stresses. Plant Physiol Bioch. 2013;67:189-98.

56. Sun XL, Yu QY, Tang LL, Ji W, Bai X, Cai H, Liu XF, Ding XD, Zhu YM. GsSRK, a G-type lectin S-receptor-like serine/threonine protein kinase, is a positive regulator of plant tolerance to salt stress. J Plant Physiol. 2013;170(5):505-15

57. Huard-Chauveau C, Perchepied L, Debieu M, Rivas S, Kroj T, Kars I, Bergelson J, Roux F, Roby D, McDowell JM. An Atypical kinase under balancing selection confers broad-spectrum disease resistance in Arabidopsis. Plos Genet. 2013;9(9):e1003766.

58. Takahashi T, Mu J, Gasch A, Chua N. Identification by PCR of receptor-like protein kinases from Arabidopsis flowers. Plant Mol Biol. 1998;37(4):587-96. 
59. Gómezgómez L, Boller T. FLS2: an LRR receptor-like kinase involved in the perception of the bacterial elicitor flagellin in Arabidopsis. Mol Cell. 2000;5(6):1003-11.

60. Lease KA, Lau NY, Schuster RA, Torii KU, Walker JC. Receptor serine/ threonine protein kinases in signalling: analysis of theerecta receptor-like kinase of Arabidopsis thaliana. New Phytol. 2010;151(1):133-43.

61. Jung CG, Hwang S, Park YC, Park HM, Kim DS, Park DH, Jang CS. Molecular characterization of the cold- and heat-induced Arabidopsis PXL1 gene and its potential role in transduction pathways under temperature fluctuations. J Plant Physiol. 2015;176:138-46.

62. Wang X, Hou S, Wu Q, Lin M, Acharya BR, Wu D, Zhang W. IDL6-HAE/HSL2 impacts pectin degradation and resistance to Pseudomonas syringae pv tomato DC3000 in Arabidopsis leaves. Plant J. 2017;89(2):250-63.

63. Zhou Y, Tan B, Luo M, Li Y, Liu C, Chen C, Yu C, Yang S, Dong S, Ruan J. Histone deacetylase 19 Interacts with HSL1 and participates in the repression of seed maturation genes in arabidopsis seedlings. Plant Cell. 2013;25(1):134-48.

64. Ranf S, Gisch N, Sch Ffer M, Illig T, Westphal L, Knirel YA, Sánchez-Carballo PM, Hringer U Z, Hückelhoven R, Lee J. A lectin S-domain receptor kinase mediates lipopolysaccharide sensing in Arabidopsis thaliana. Nat Immunol. 2015;16(4):426-33.

65. Letunic I, Doerks T, Bork P. SMART: recent updates, new developments and status in 2015. Nucleic Acids Res. 2015;43(D1):D257-60.

66. Sudhir K, Glen S, Koichiro T. MEGA7: molecular evolutionary genetics analysis version 7.0 for bigger datasets. Mol Biol Evol. 2016;33(7):1870-4.
67. Magalh Es DM, Scholte LLS, Silva NV, Oliveira GC, Zipfel C, Takita MA, De Souza AA. LRR-RLK family from two Citrus species: genome-wide identification and evolutionary aspects. BMC Genomics. 2016;17(1):623.

68. Yupeng W, Haibao T, DJ D, Xu T, Jingping L, Xiyin W, Tae-ho L, Huizhe J, Barry M, Hui G, et al. MCScanX: a toolkit for detection and evolutionary analysis of gene synteny and collinearity. Nucl Acids Res. 2012;40(7):e49.

69. Chen C, Chen H, Zhang Y, Thomas HR, Xia R. TBtools: an integrative toolkit developed for interactive analyses of big biological data. Mol Plant. 2020;13(8):1194-202.

70. Koch MA, Bernhard H, Thomas M. Comparative evolutionary analysis of chalcone synthase and alcohol dehydrogenase loci in arabidopsis, arabis, and related genera (Brassicaceae). Mole Biol Evol. 2000;10:10.

71. Sawyer SA. Statistical tests for detecting gene conversion. Mol Biol Evol. 1989;6(5):526-38.

72. Hu B, Jin J, Guo AY, Zhang H, Gao G. GSDS 2.0: An upgraded gene feature visualization server. Bioinformatics. 2014;31(8):1296.

73. BT L, Mikael B, Buske A F, F Martin, Grant C E, Luca C, Jingyuan R, Li W W, Noble SW. MEME Suite: tools for motif discovery and searching. Narnia. 2009;37(suppl2):W202-8.

\section{Publisher's Note}

Springer Nature remains neutral with regard to jurisdictional claims in published maps and institutional affiliations.
Ready to submit your research? Choose BMC and benefit from:

- fast, convenient online submission

- thorough peer review by experienced researchers in your field

- rapid publication on acceptance

- support for research data, including large and complex data types

- gold Open Access which fosters wider collaboration and increased citations

- maximum visibility for your research: over 100M website views per year

At BMC, research is always in progress.

Learn more biomedcentral.com/submissions 